\title{
İSLÂM HUKUKUNDA ARABULUCULUK
}

\section{Özet}

Uyuşmazlıkların çözümü her hukuk sistemi tarafından yerine getirilmesi gereken en önemli konudur. Aralarında anlaşmazlık yaşayan insanlar, sorunlarını, arabuluculuk, tahkim, sulh ve mahkeme yoluyla çözüme kavuşturmaktadır. Bu makalede uyuşmazlık çözüm yöntemlerinden biri olan arabuluculuğa dikkat çekilmiştir. Arabuluculukla ilgili kavram analizi yapılmış, ayrıca sulh ile diğer uyuşmazlık çözüm yöntemleri karşılaştırılmıştır. İslâm hukukunda Arabuluculuğun temellendirilmesi olarak Kur'an'da ve Hz. Peygamberin uygulamalarında arabuluculuk üzerinde durulmuş, Arabuluculuğun işleyiş süreci ve Arabuluculuğun günümüzde uygulanışı ele alınarak, Arabulucuda bulunması gereken şartlar açıklanmıştır. Makale, kanaat ve değerlendirmelerin yer aldığı sonuç kısmıyla bitirilmiştir.

Anahtar kelimeler: Arabuluculuk, Sulh, Tahkim, Mahkeme, Uyuşmazlık çözümü.

\section{Abstract}

\section{Mediation in Islamic Jurisprudence}

The conflict resolution is the most fundamental matter that is all legal systems must carry out. People who have problems between themselves find solutions to their issues through the reconcilation, the mediation, the peace/sulh, the arbitration/consolidation and the court of law. In this paper mediation is pointed out as one of the methods of the conflict resolution. Concept analysis regarding to the meditaon is being made and also the comparision between "sulh/peace" and other conflict resolution methods are being done. In order to provide adequate ground for the mediation, the Quran and the prophet's practices are examined. Morever, the application of the mediation in the contemprary world is discussed. The procces of the mediation and the qualifications that are asked from the mediator are explained. The paper is ended at the conclusion part with the thoughts and the considerations.

Keywords: Mediation, Peace/sulh, Arbitration/concoliditon, Court of law, Conflict resolution.

\section{Giriş}

Sosyal bir varlık olan insanın tek başına yaşaması mümkün değildir. İnsan kendi ihtiyaçlarını karşılayabilmek için mutlaka bir başkasının varlığına muhtaçtır. Kendi ihtiyaçlarını karşılayıp hayatını sürdürürken diğer insanlarla ihtilaf etmesi, uyuşmazlık yaşaması insanın fıtratında olan tabii bir durumdur. ${ }^{1}$

* $\quad$ Yrd. Doç. Dr., Bayburt Ü. İlahiyat Fakültesi

1 Buharî, es-Sahîh, Enbiyâ 19; Müslim, el-Câmiu's-sahîh, Fedâilü's-sahabe 199; Ahmed b. Hanbel, 
Allah insanları yaratırken her birini farklı kabiliyet ve farklı özelliklerle bezeyip yeryüzüne göndermiştir. İnsanların farklı istek ve çıkarları zaman zaman birbirleriyle çatışmış, bunun sonucu olarak bir takım ihtilaflar ve anlaşmazlıklar ortaya çıkmıştır.

Sosyal bir çevrede yaşaması fıtrî olan insanların aralarındaki farklı görüş ve ihtilafların çözüme kavuşturulması, aynı zamanda toplumsal gelişmenin en temel dinamiklerinden biridir. Çünkü farklılıklar insanların her alanda tekâmül etmesine yardımcı unsurlardır. Bunun rahmete dönüşüp toplum yararına olması, ancak ihtilaf ve uyuşmazlıkların İslâm'ın genel amaçlarına uygun olarak çözülmesiyle mümkündür. ${ }^{2}$

Üzerinde duracağımız konu, kul haklarını ilgilendiren, uyuşmazlıkların sona erdirilmesindeki ilk aşama olan süreçtir. Şüphesiz iki taraf arasında meydana gelen sorunların hukuki bağlamda son mercii mahkemelerdir. Ancak mahkeme aşamasına gelmeden toplumda sulh ve sükûnu sağlamak, Hz. Peygamber' in ifadesiyle toplumu bir vücudun organları haline getirmek, insanların memnun olacağı ve sonuçta uyuşmazlıkların karşılıklı rızaya dayanarak çözülmesi mutlu bir toplum olmada önemli bir faktör olarak karşımıza çıkmaktadır. Huzurlu insanlardan teşekkül eden bir toplumu meydana getirmek, yarg1 aşamasına gelmeden ihtilaf ve uyuşmazlıkların çözülmesine büyük katkı sağlayacağına kuşku yoktur. Mahkeme aşaması da dâhil olmak üzere, uyuşmazlık çözümünde birçok yollar bulunmaktadır. Bunlardan biri de arabuluculuk müessesesidir. Bu makalede arabuluculuğun İslâm hukukunda temellendirilmesi ve işleyişi üzerinde durulacaktır. Bunun yanında farklı uygulama örnekleriyle arabuluculuk müessesesine dikkat çekilecektir.

\section{Kavramsal Çerçeve}

Konunun bütün yönleriyle değerlendirilebilmesi için kavramsal çerçevesinin ortaya konulması gerekmektedir. Çalışmamızla ilgili olarak sulh, tahkim muhâkeme ve teklif edeceğimiz arabuluculuk kavramlarına yer vermenin isabetli olacağını düşünüyoruz.

\subsection{Sulh}

Kelime olarak, s-l-h kökünden türeyen, uzlaşma ve barış anlamlarına gelen

el-Müsned, c. 2, s. 260, 391

2 Hayreddin Karaman, İslâm'ın Işı̆̆ııda Günün Meseleleri, Nesil Yay., İstanbul 1992, c. 3, s. 467. 
sulh, ${ }^{3}$ fesadın zıddıdır. İslâm Hukuku literatüründe ise; her iki taraf arasında meydana gelen ihtilaf ve nizaları, karşılıklı rıza ile ortadan kaldırmak için, tarafların yaptığı anlaşma akdi ${ }^{4}$ olarak ifade edilir. Sulh kavramı ile ilgili yapılan tariflerin ortak yönü, taraflar arasındaki ihtilaf mevzuunun ortadan kaldırılmasıdır. ${ }^{5}$ Sulhde davayı açma ve bir bedel karşılığında sulh olma, muhtemel bir ihtilafın önüne geçme söz konusudur. ${ }^{6}$

Kitabü's-sulh bölümü, f1kıh kitaplarında Kitabü'ş-şehâde, Bâbü'd-da'va, İkrar bölümlerinden sonra gelir ve konu müstakil olarak işlenir.7 Sulh konusu, Musâlaha, muâhade gibi kavramlarla, İslâm devletinin diğer devletlerle yaptığ 1 sulh anlamındaki anlaşmalar siyer bölümlerinde, eşler arasındaki anlaşmazlıklarla ilgili sulh nikâh bölümlerinde, devam eden bir davada tarafların sulh olmaları edebü'l-kâdî, cinâyet ve kısas bölümlerinde, malî konularla ilgili ihtilaflar sulh bölümünde, ferâizle ilgili olanlar ise tehâruc alt başlığında, Mecelle'de 8

3 Mehmet Erdoğan, Fikıh ve Hukuk Terimleri Sözlüğü, Ensar Neşriyat, İstanbul 2010, s. 513.

4 Muvaffakuddîn Ibn Kudâme, eş-Şerhu'l-kebîr, Beyrut 1972; c. 5, s. 2; Heyet, el-Fetevayi Hindiyye Bulak 1310, c. 4, s. 228; Ebû'l-Hasan Ali b.Muhammed b.Habîb el-Mâverdî, el-Hâvi'l-kebîr fî fikhi mezhebi'l-imam eş-şafî̀ ve hüve şerhu muhtasari'l-müzen̂̂, tahk.: Şeyh Ali Muhammed Muavvıd, Şeyh Adil Ahmed Abdul Mevcut, Daru'1 Kütübi'l-ilmiyye, Beyrut 1994, c. 6, s. 370; Mecelle, Md. 1531.

5 Davud Yaylalı, İslâm Hukukunda Sulh, Taştan Matbaacılık, İstanbul 1993, s. 13. Örnek olarak bk. Şer'iye Sicilleri, Türk Dünyası Araştırma Vakfı Yay., İstanbul 1989, c. 2, s. 237.

6 Türk Hukuk Lügati, s. 305.

Örnek bir uzlaştırma kararı: “İstanbul'da Kilise Camii Mahallesinde vefat eden gayrı müslim olan Marule' den intikal eden ev miras yoluyla öz oğlu Toma'ya ve diğer oğlu Yâni'ye kalmıştır. Ancak Toma'nın müslüman olan oğlu Mustafa ile Yâni'nin oğulları Manul ve Düka arasında çıkan anlaşmazlıkla ilgili olarak müslüman olan Mustafa şer'î yargı meclisinde şu açılamalarda bulunmuştur: Babam vefat ettiğinde mezkür yarım hissesi ben Müslüman olmadan önce bana intikal etmiştir. Bu sebeple adı geçen iki şahısla dava ve çekişme içindeydim. Şu anda aramıza muslihûn/uzlaştırıcılar girerek 800 geçerli nakit akçe karşılığında bizi sulh yapmak istediler. Ben de söz konusu bu sulh akdini kabul ettim ve sulh bedeli olan 800 akçelik meblağ tam olarak teslim aldım. Bu konuyla ilgili bütün davalardan davalılar Manul ve Düka'nın zimmetlerini umumî bir ibrâ ile ibrâ ettim. Bu günden sonra, hiçbir şekilde asaleten ve vekâleten bir dava açılırsa, değerli hâkimler katında kabul edilmesin. Davacının bu ikrarını davalılar Manul ve Düka sözlü olarak aynı mecliste tasdik edince, durum olduğu gibi talep üzerine sicile kaydedildi." Şer'iye Sicilleri, c. 2, s. 237.

7 Örnek olarak bk. Muhammed b. Ahmed, Ebî Sehl Şemsuddin es-Serahsî, el-Mebsût, Daru'1Ma'rife, Beyrut 1989, c. 20, s. 133; Ebû İshak İbrahim b. Ali b.Yûsuf el-Fîrûzâbâdî eş-Şînâzi, elMühezzeb fi fikhi mezhebi'l-imâm eş-Şâfî̀, tahk.: Adil Ahmed Mevcûd, Daru'l-Ma'rife, Beyrut 2003, c. 2, s. 223; Ebû Muhammed Ali b. Ahmed Ibn Hazm, el-Muhalla, tahk.: Muhammed Münîr, İdaratü't-Tıba'ati'l-Müniriyye, Mısır 1352, c. 8, s.160. Mecelle, Md. 1531-1571. 
ise ibra konusuyla beraber ele alınmaktadır. ${ }^{9}$

\subsection{Tahkîm}

Tef'il babından bir masdar olan tahkim, hakem tayin ederek hüküm vermesini istemek, anlamına gelir. İslâm hukuku literatüründe ise, "İhtilaf ve uyuşmazl1ğa düşen tarafların, ihtilaflarını çözmek için kendi rızaları ile üçüncü kişi ya da kişileri hakem tayin etmeleri ve bu konuda yaptıkları sözleşmedir. ${ }^{10}$ Hakem ve tahkimle ilgili kelimeler Kur'an'da ve hadislerde geçmektedir. ${ }^{11}$

İslâm öncesi dönemde yaygın olarak kullanılan tahkim çözüm yolu, İslâm sonrası da meşru kılınmış, hâkimde aranan şartların hakemde de olması gerektiği, İslâm hukukçuları tarafından belirtilmiştir.12

Tahkimin uygulandığı alanlar sulhda olduğu gibi kul haklarının geçerli olduğu alanlardır. Tahkim bir çeşit sulh olduğundan, sulhun geçerli olmadığ durumlarda tahkim de geçerli değildir. Allah ve kul haklarının birlikte bulunduğu zina iftirası cezası gibi durumlarda tahkimin uygulanması tartışmalı bir konudur. ${ }^{13}$

Tahkim ile yargı arasında farklar bulunmaktadır: Hâkim görevlendirildiği yerde gelen tüm davalara bakarken, hakem sadece hakem olduğu taraflar arasında hakemlik yapabilir. Hakemin görevini yerine getirebilmesi için tarafların rızası gerekir. Ayrıca görev yeri, verilen kararın etkisi, ispat delillerinin kullanılması bakımından da farklar vardır. ${ }^{14}$

9 Daha geniş bilgi için bk. Nezih Hammad, Akdü's-sulh fi'ş-şerîati'l-İslâmiyye, Beyrut 1996; Mahmûd Mahcûb Abdunnûr, es-Sulh ve eseruh fì inhâi'l-husûme fi'l-fikhı'l-İslâmî, Beyrut 1987; Fahrettin Atar, "Sulh", DİA, İstanbul 2009, c. 37, ss. 481-485; Ahmet Yaman,"Sulh" DİA, İstanbul 2009, c. 37, ss. 485-489; Yaylalı, İslâm Hukukunda Sulh, s. 17.

10 Ömer Nasuhi Bilmen, Hukukı İslâmîyye ve Istılahatı Fıkhıyye Kamusu, Bilmen Yay., İstanbul 1986, c. 8, s. 250; Örnek için bk. Muhammed Hamidullah, İslâm Peygamberi, çev.: Salih Tuğ, İrfan Yay., İstanbul 1991, c.2, s. 923; Ali Himmet Berki, Açıklamalı Mecelle, Hikmet Yay., İstanbul 1990, s. 406,420.

11 Mâide, 5/43; Nisâ, 4/65; Buharî, es-Sahîh, Enbiya 40, 54; Müslim, el-Câmiu's-sahîh, Akdiye 20, 21. Ayrıca diğer hadisler için bk. Wensinck, el-Mu'cemül-müfehres li'l-elfâzı'l-hadîsi'n-nebeviyyi, Çağrı Yay., İstanbul 1988, c.1, ss.489-491.

12 Alâuddîn Ebu'l-Hüseyn Ali b. Halil Tarablûsî, Muînu'l-hükkâm fî mâ yeteraddedu beynelhasmeyn mine'l-ahkâm, Misır 1973, s.27; Abdullah b. Mahmud b. Mevdud el-Mavsılî, Kitâbu'lihtiyar li ta'lîli'l-muhtar, Dâru'l-Ma'rife, Beyrut 2010, c. 2, s.111.

13 Abdurrahman b. Muhammed en-Necdî, Hâşiyetü'r-ravzı'l-mürbi', Beyrut 1983, c.7, s.521.

14 Detay için bk. Mustafa Ahmed, ez-Zerkâ, el-Fikhu'l-İslâmîfí sevbihi'l-cedîd, Dâru'l-Fikr, Dımeşk 1967, c.1, s. 555. Daha geniş bilgi için bk. Kahtân, Abdurrahman ed-Dûrî, Akdü't-tahkîm fi't- 
Bu bağlamda hakemler icra ettiği görevler bakımından, sslah görevi olan arabulucu ile resmî görevi olan kadı arasında bir konumda bulunmaktadırlar. ${ }^{15}$ Ancak tarafların istemesi halinde hakemler arabulucu olarak ${ }^{16}$ ihtilaf ve uyuşmazlıkları çözüme kavuşturarak sulh aşamasına geçebilirler. ${ }^{17} \mathrm{Bu}$ durumda sulh tarafların yaptığı bir akit olmakla birlikte tahkim kazaî bir hüküm olarak ortaya çıkmaktadır.

\subsection{Muhâkeme}

Muhâkeme, tarafların aralarındaki ihtilafın veya müddeâbih'in çözümü noktasında ispat delillerine dayanarak adaletli olarak hâkimin karar vermesidir. ${ }^{18}$

Muhâkemenin tarihi seyrine bakıldığında gelişme içerisinde olduğu görülecektir. İslâm'ın ilk devirlerinde yargılama tahkim usulüne yakın basit ve sadeydi. Davacı iddia ve delilleriyle birlikte kadının huzuruna gelir O'na arz ederdi. Kadı da bu delillere göre hüküm verirdi. Kısas, had gibi ceza davalarına halife ve valiler bakarken, daha sonra ceza ve hukuk davalarına kadılar bakmaya başlamıştır.

Mahkemeler ilk devirlerde kadılarla anılır olmuş, kazâ ile ilgili terimler yerini hâkime bırakmıştır. Mahkemeler zamanla görevlerinin bir kısmını mezâlim, şurta, hisbe gibi kurumlara devretmiştir. ${ }^{19}$

Taraflar arasındaki davalar önceleri tek hâkimli ve tek dereceli mahkemelerde çözüme kavuşturulmuştur. Tarihi süreçiçerisinde çok hâkimli mahkemelerde de görülmeye başlanmıştır.

Osmanlılarda ise muhâkeme usulü diğer İslâm devletlerine göre daha da gelişmiş durumdaydı. Osmanlı muhâkeme sistemi hem şer'î hem de örfî huku-

fikhı'l-İslâmîve'l-kânûni'l-vaz'̂̉, Bağdat 1985; Mustafa Yıldırım, “Tahkim” DİA, İstanbul 2010, c. 39, ss. 411-413; Hüseyin Çeliker, "İslâm Hukukunda Tahkim", Diyanet Illmi Dergi, Ankara 2005, c. 41, sayı:1, ss.17-46.

15 Ahmet Akgündüz, “Hakem” DİA, İstanbul 1997, c.15, s.172.

16 Ebû Bekr Ahmed b. Ali er-Râzî el-Cassâs, Ahkâmü'l-Kur'ân, tahk.: Abdüsselâm Muhammed Ali Şahin, Dâru'l-Kütübi'l-İlmiyye, Lübnan 2007, c. 2, s. 240; Süleyman Ateş, Kur'an Ansiklopedisi, Kur'an Bilimleri Araştırma Vakfı, İstanbul ts.; c.3, ss.146-148.

17 Fahruddîn Osman b. Ali ez-Zeylâî, Tebyînu'l-hakâik şerhu kenzi'd-dakâik, Dâru'l-Kütübi'lilmiyye, Beyrut 2000, c.5, s.117.

18 Muhakeme usulü için bk. Abdülaziz Bayındır, İslâm Muhakeme Hukuku, İslâmî İlimler Araştırma Vakfı Yay., İstanbul 1986, s.79; Hamidullah, İslâm Peygamberi, c. 2, s. 928.

19 Fahrettin Atar, "Mahkeme", DİA, İstanbul 2003, c. 27, s. 338,340. 
ku uygulamaktaydı. Bu durum diğer İslâm devletlerinde mezalim şurta gibi yargı kurumlarının sebep olabileceği karışıklıkları önlemiştir. ${ }^{20}$

Muhâkeme aşamasında yargılamanın alenî yapıldığını gözlemleyen şuhûdül-hâl, sanıkların mahkemeye getirilmesinde görevli muhzırlar kadıya yardımcı olarak görev yapmaktaydı. ${ }^{21}$ Osmanlı muhâkeme sisteminde kadıya yardımcı unsurlar arasında, tarafların anlaşmayla sonuca varmalarında önemli rolü bulunan ve yaygın olarak görev yapan ancak ismi pek zikredilmeyen arabulucular muslihûn da bulunmaktadır. Müftîler de dînî-hukukî konularda dolaylı olarak mahkemeye yardımcı olmuş, arabulucu rolünde bulunmuşlardır. ${ }^{22}$

\subsection{Arabuluculuk}

Arabuluculuk (ıslah, ıslah-ı zati'l-beyn), taraflar arasındaki uyuşmazlıkların kendi istekleriyle ${ }^{23}$ ve üçüncü kişi yardımıyla tavsiye ve telkinlerle ${ }^{24}$ çözüme kavuşturulmasıdır. İslâm hukuku literatüründe üçüncü kişi olarak muslih ${ }^{25}$ kavramıyla ifade edilen arabuluculuk, aynı zamanda mahkeme sürecinin başlangıcında olan ve tarafların memnuniyeti esasına dayanan bir uyuşmazlık çözüm yoludur. ${ }^{26}$ Hâkimin vereceği karar, her zaman davacı (müddeî) ve davalı (müddeâ aleyhi)yı memnun etmeyebilir. Bu nedenle hâkim tarafları arabulucuya veya sulh olmaya yönlendirebilir. ${ }^{27}$ Nitekim Hz. Peygamber' in uygulamalarında bu tür örnekleri görmek mümkündür. ${ }^{28}$

Sulh, tahkim, muhâkeme ve arabuluculuk kavramları arasında bulunan farklılıkları şu şekilde izah etmek mümkündür: Uzlaşmazlık konularının yargıya/mahkemeye intikal etmesi durumunda son kararı hâkim verir. Tahkimde ise kararı hakem verir. Tarafların hakeme yetki vermeleri

20 M. Akif Aydın, "Mahkeme”, DİA, İstanbul 2003, c. 27, ss. 342-344.

21 Kadıya yardımcı diğer memurlar için bk., Fahrettin Atar, İslâm Adliye Teşkilâtı, Diyanet İşleri Başkanlığı Yay., Ankara 1991, ss.122-149.

22 M. Akif Aydın, "Mahkeme”, DIA, c. 27, s. 343.

23 Türk Hukuk Lügati, Maarif Matbaası, Ankara 1944, s. 305.

24 Süha Tanrıver, “Alternatif Uyuşmazlık Çözüm Yolları”, ss. 165-166; Şafak, Hukuk Terimleri Sözlüğ̈̈, Rehber Yay., Ankara 1992, s. 34.

25 Şemsüddîn Ebî Abdillah Muhammed b. Ebî Bekr İbn el-Kayyim el-Cevziyye, Îlâmü'lmuvakkı̂n an rabbi'l-âlemîn, Dâru'l-Cîl, Beyrut ty. c. 1, s. 110.

26 Hayreddin Karaman, Bă̆layıcılık Bakımından Rasûlullah'ın Davranışları, (Hz Peygamber ve Aile Hayatı İçinde), İlmi Neşriyat, İstanbul 1989, s. 142.

27 Atar, İslâm Adliye Teşkilâtı, s.193; Bilmen, Fıkhıyye Kamusu, c. 8, s. 228.

28 Bk. Beyhakî, es-Sünenü'l-Kübrâ, Sulh 1, 5; İbn el-Kayyim, I'lâmü'l-muvakkı̂̂n, c. 1, s. 107. 
durumunda verilen karar bağlayıcıdır. Arabuluculukta kararı taraflar verir. Arabulucu, tarafların arasını bularak onları ortak noktaya getirmeye çalışır.

Ayrıca yargılama aşaması değerlendirildiğinde mahkemede belirlenmiş şeklî bir süreç vardır. Tarafların belirli bir yerde yani mahkemede hâkimin huzurunda olması gerekir. Tahkimde bu süreç mahkemeye göre daha azdır. Arabuluculukta ise çok daha azdır. Mahkemeden, tahkime ve arabuluculuğa çoktan aza doğru şeklî süreç devam eder. En az şekli süreç arabuluculukta mevcuttur. Çünkü taraflar mahkeme dişında herhangi bir yerde arabulucu aracıllğıyla uyuşmazlıklarını görüşüp karara varabilirler.

Diğer taraftan Mahkemeye ulaşan davalarda ispat vasıtalarına göre karar verilir. İslâm muhâkeme hukukunda yemin, şahitlik, yeminden nükûl, karîne vb. ispat vasıtası olarak kullanılır. ${ }^{29}$ Tahkimde ise ispat vasıtaları biraz daha yumuşatılarak değerlendirilir. Arabuluculukta ise hiç kullanılmaz. Arabuluculukta aslolan tarafların bizzat kendilerinin niza konusunu çözüp anlaşmalarıdır. Arabuluculukta tarafların anlaşması daha çok gönüllülük ve fedâkârlık ${ }^{30}$ esasına göre işler. Zaten taraflar isterlerse arabulucuyu kendilerine sorunun çözülmesi noktasında yardım etmek için tayin ederler.

Tahkim, arabuluculuk ve sulh akdinin uyuşmazlık çözüm yolu olarak kullanıldığı alanlar kul haklarının geçerli olduğu durumlardır. ${ }^{31}$ İslâm ceza hukukunda kul haklarını ilgilendiren, kısas ve diyet gerektiren hallerde af veya bir bedelle sulh olmak da câiz görülmüştür. ${ }^{32}$

İslâm muhâkeme hukukunda, yargılamada diğer bir ifadeyle mahkemede taraflar haklarını savunurken hâkim olayın keşfini gerekli görmesi halinde keşif yapabilir. Hâkim bilirkişi olan ehl-i hibreden yardım alabilir. Ehl-i hibre, hâkimin karar vermesinde etkili olabilmektedir. Tahkimde keşif daha dar kapsamda olmaktadır ve sınırlıdır. Arabuluculukta ise daha çok vakıalar tespit edilmekte keşif zorunlu olmamakta ve hatta keşif yapılmamaktadır.

29 Atar, İslâm Adliye Teşkilâtı, s. 195.

30 Karaman, Bağlayıcılık Bakımından Rasûlullah'ın Davranışları, s. 142.

31 Şîrâzi, el-Mühezzeb, c. 3, s. 593; Mavsılî, Kitâbu'l-ihtiyar, c. 2, s. 111.

32 Şihâbuddîn Ahmed b. İdris el-Karafî, ez-Zehîra, tahk.:Muhammed Haciy, Daru'1- Garbi'1 İslâmî, Beyrut 1994, c. 5, ss. 336-344; Abdulkadir Avdeh, et-Teşri'u'l-cinâi'l-islâmî mukârenen bi'l-kânûni'l-vad'i, Dârü'l-Kütübi'l-Arabi, Beyrut t.y. c. 2, s. 158; Şamil Dağcı, İslâm Ceza Hukukunda Şahıslara Karşı Müessir Fiiller, Diyanet İşleri Başkanlığı Yay., Ankara 1996, s. 124; Yaylalı, İslâm Hukukunda Sulh, s. 145. 
Mahkeme sürecinde önemli olan hakların zayi olmaması, kısa sürede hakların yerini bulması, her hak sahibinin yok olan hakkına kavuşmasıdır. Bu süreçte hak ararken hak kaybına uğramadan sonuca varılması yargılamanın amaçlarındandır. Uyuşmazlıkların çözüm sürecine baktığımızda yargı yolunun tahkim ve arabuluculuğa göre daha zaman alıcı ve masraflı olduğunu ifade edebiliriz. Çünkü hem mahkeme aşamasına gelinceye kadar hem de mahkeme sürecinde zaman ve ekonomik olarak daha fazla gayret sarfedildiği bilinen bir gerçektir. Tahkimde ise daha az masraf ve zaman kaybı olmaktadır. Çünkü daha az şeklî süreç ve işleyiş mevcuttur. Arabuluculukta ise çözüm taraflara ve arabulucunun performansına bağlı olmakla birlikte süreç daha hizlı ve daha az meşakkatli olmaktadır.

Mahkeme süreci kamuya açık olurken tahkimde ve özellikle karı koca anlaşmazlıklarında aile meclislerine açık olmaktadır. ${ }^{33}$ Arabuluculukta ise süreç tamamen taraflar arasında kalmakta ve gizli olmaktadır. Arabuluculuktan mahkemeye kadar, özelden genele doğru bir metot izlenmekte, her iki taraf açısından sonuçtan memnuniyet azalabilmektedir.

Arabuluculuğun temel işlevine baktığımızda da mahkeme ve tahkimden ayrıldığı görülmektedir. Çünkü arabulucu hakem ve hâkimden farklı olarak tarafları bağlayıcı karar verememektedir. Ancak uyuşmazlık yaşayan taraflara karşılıklı olarak anlaşmaya varmalarına yardımc1 ${ }^{34}$ ve sulhun ön aşamalarından biri olmaktadır.

\section{Sulh Akdinin Ön Aşaması Olarak Arabuluculuk}

Anlaşmazlıkların sona erdirilmesinde taraflar arasında bir akit olan sulhun, ${ }^{35}$ in'ikadi için unsurları olan îcab ve kabulün, akdi yapan tarafların/âkidân, sulh bedelinin/musâlehun aleyh ve sulh mahallinin/musâlehunanh ${ }^{36}$ bulunması gerekir. Diğer anlaşmazlık çözüm yöntemlerinde bu özelliği görmemekteyiz. Sulh bir sonuç olarak akdin gerçekleşmesi ve çözümün ortaya çıkmasıdır. Sulh akdinin ön aşaması olan arabuluculuk sulha ulaşmaya itici güç durumundadır. Sulh

33 Zerkâ, el-Fıkhu'l-İslâmî fî sevbihi'l-cedîd, c.1, s. 555.

34 Mustafa Serdar Özbek, "Alternatif Uyuşmazlık Çözüm Yollarına Genel Bir Bakış”, Galatasaray Üniversitesi Hukuk Fakültesi Dergisi, İstanbul 2004, sayı:1, ss.261-292.

35 Serahsî, Mebsut, c. 2, s. 133; Orhan Çeker, İslâm Hukukunda Akitler, İttifak Holding Yay., Konya 1999, s. 215.

36 Mecelle, Md. 1842, Zerkâ, el-Fıkhu'l-İslâmî fî sevbihi'l-cedîd ,c.1, s. 554; 
olan taraflar, akitlerini yaz1l ${ }^{37}$ ve sulh bedeli vererek yaparken arabuluculukta bunu yapmaları söz konusu değildir. Arabuluculuk sulha göre daha esnek olmaktadır. Arabuluculuk bir akit olmaması, yazılı bir belgeye dönüştürülmemesi ve sulh bedelinin bulunmaması yönleriyle sulhdan farklıdır. Sulh bir şemsiye kavram olarak arabuluculuğu kapsarken diğer farklı özellikleriyle arabuluculuktan ayrilır.

Arabuluculuk, sulh kavramı ve içeriği düşünüldügünde, gerçekleştirmek istediği amaçlar açısından genişletici ve kolaylaştırıcı bir süreçtir.

İslâm hukukunda sulhun gerçekleşebilmesi için davanın açılmış olması gerekirken, ${ }^{38}$ arabuluculuk dava açıldıktan sonra veya açılmadan önce olabilmektedir.

Ayrıca sulh akdi, akitlerin hangisine benziyorsa o akdin hükmünü alması yönüyle farklılık arz eder. Menfaat üzerine yapılan sulh kira akdi hükmünde, malla yapılan sulhlar bey' akdi hükmünde değerlendirilir. ${ }^{39}$

Sulh aracıları olan arabulucuların, uyuşmazlıkları çözmesi, Hz. Peygamberin uygulamalarında olduğu gibi önemli bir süreçtir. Hz. Peygamber, uygulamalarıyla, toplum içerisinde itibarlı ve etkili kişilere uyuşmazlıkların nasıl çözdürüleceği konusunda en güzel örnek olmuştur. Bu çözüm yolu yanında sulh, yargıya başvurma, tahkim ve bir kuruluş olarak Hisbe Teşkilâtı, ${ }^{40}$ Mezâlim Mahkemeleri, ${ }^{41}$ Sâhibü'ş-Şurta, ${ }^{42}$ Kâdı'1-Asker ${ }^{43}$ de mahkemelere yardımcı ola-

37 Yaylalı, İslâm Hukukunda Sulh, s. 33.

38 Yaylalı, İslâm Hukukunda Sulh, s. 14.

39 Serahsî, Mebsut, c. 20, s. 14.

40 Hisbe Teşkilâtı, İslâm hukukuna göre iyiliği emir, kötülükten yasaklamak üzere kurulan bir teşkilattır. Burada görevli olanlara muhtesib denir. Hz. Peygamber zamanında bu görevi Hz. Ömer' in yürüttüğü bilinmektedir. Ayrıca hisbe teşkilâtı taraflardan birinin haksızlık yapması ve hakkı teslim etmemekte direnmesi durumunda hisbe görevlileri duruma müdahale eder hak sahibinin hakkını vermeye çalışır anlaşmazlıkları çözerdi. Günümüzde özellikle işçi ve işveren arasındaki anlaşmazlıkların sürüncemede kalmaması ve amme menfaatini gözetme açısından hisbe teşkilatı gibi tarafsız bir kuruluşun olmasının önemi büyüktür. Karaman, İslâmın Işı̆̆ııda Günün Meseleleri, c.1, ss. 406- 407. Geniş bilgi için bk. Abdurrahman b. Nasr Şeyzerî, İslâm Devletinde Hisbe Teşkilâtı, haz.: Abdullah Tunca, Ma'rifet Yay., İstanbul 1993, ss.15-38.

41 Halk Divânı ve Mezâlim Divanı gibi isimler verilen, normal yargının dışında idarecilerin yaptığı haksızlıklara karşı açılan davaların görüşüldüğü özel mahkemelerdir. Atar, İslâm Adliye Teşkilâtı, ss. 167-174; Şafak, Hukuk Terimleri, ss. 331-332.

42 Sâhibü'l-Şurta, muhakeme aşamasında hâkimlere yardım etme, hüküm verme ve tahkikat yapma gibi görevleri vardır.

43 Kâdı'l-Asker, İslâm devletinde ordu mensuplarını ilgilendiren davalara bakma yetkisi olan 
rak, İslâm hukukçuları tarafından ifade edilmiştir. ${ }^{44}$ Söz konusu kuruluşların amacı, tarafların ihtilaflarını ortadan kaldırmak, her hak sahibine hakkını vermek, sulha kavuşturmaktır. Arabuluculuk, bütün bu süreçlerin başlangıcı olarak tezahür eder.

Uyuşmazlık çözüm yollarının sonucu olan sulh vasıtalarını aşağıdaki şekilde şematize edebiliriz.

Uyuşmazlıkların Çözüm Yolları

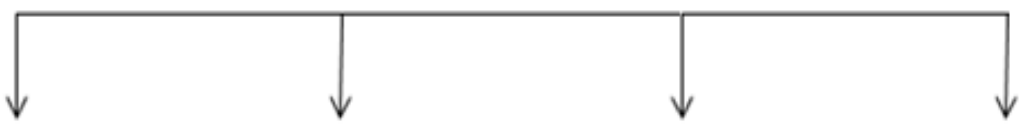

$\begin{array}{llll}\text { Uzlaşma } & \text { Arabuluculuk } & \text { Hisbe Teşkilatı } & \text { Tahkim }\end{array}$

Bunlar arasında Sulhun ön aşaması olan arabuluculuk kendi içinde işleyişi olan, yargıya yardımcı olmasıyla İslâm muhâkeme hukukunda değerlendirilen uyuşmazlık çözüm yollarından biridir. Ancak arabuluculuğun yargı görevini icra etme ve taraflar istemediği sürece bağlayıcı olma özelliği bulunmamaktadir.

\section{4. İslâm Hukukunda Arabuluculuk}

\subsection{Hukukî Dayanağı}

Arabuluculuk; farklı kavramlarla, İslâm hukukunun kaynakları olan Kur'an, Sünnet ve Sahabe uygulamalarıyla meşru kılınmıştır.

\subsubsection{Kur'ân'da}

Kur'ânî bir kavram olan Sulh bir akit olarak anlaşmazlıkların sona erdirilmesinde bir sonuçsa, arabuluculuk da bu sürece yardım eden ön aşamadır.

İnsanların arasının düzeltilmesi, toplumda barış ve huzurun sağlanması, "kardeşlerinizin arasını düzeltin" ıslâhu zâti'l-beyn İslâm hukukunun amaçları açısından hassasiyetle üzerinde durduğu bir konudur. Çünkü ayrılığa düşmemek ve ihtilafları çözüme kavuşturup toplumda birliği sağlamak, Kur'an'ın âmir hükmüdür. ${ }^{45}$

mahkemelerdir.

44 Karaman, İslâmın Işı̆̆̆ında Günün Meseleleri, c. 1, ss. 404-408; Atar, İslâm Adliye Teşkilâtı, s. 167.

45 Hucurât, 49/9, 10; Âl-i İmran, 3/103. 
İhtilaflı konuların her iki tarafın memnun olacağı şekilde sonuçlandırılması ve ayrılıkların bertaraf edilmesi hem taraflar ve hem de yaşanılan toplum için önemlidir. İfsâdü zâti'l-beyn ${ }^{46}$ yani insanların arasını açmak, düşmanlıklar, ayrılıklar yasaklanmıştır. “Parçalanıp ayrılmayın” âmir hükmü ile anlatılmak istenen insanların gelişmesine medar olacak farklılıklar değil, müslüman toplumu fesada götürecek ayrılıklar kastedilmiştir. ${ }^{47}$ Kur'an'a ve Sünnete aykırı olan ihtilaflar ve hak kayıpları toplumda birliği zedeleyen en önemli unsurlardır. Şüphesiz dünya ve ahiret maslahatları Kur'an'a ve Sünnete sarılmakla mümkündür. ${ }^{48}$

Arabuluculuk temelde Kur'ânî olmakla birlikte, hem ahlâkî ve hem de hukûkî bir terimdir. Hukûkî olması uyuşmazlıklarda çözüm sürecinin bir parçası olması ve yargıya yardım etmesinden kaynaklanır. İnsanların çekişmelerinin çözümle sonlanması, aralarının yapılmasından geçmektedir. Bunun yolunu Allah Kur'an'da şöyle ifâde eder: “Allah'a ve O'nun Resûlü'ne itaat edin. Birbirinizle çekişmeyin. Sonra korku ile zaafa düşersiniz, kuvvetiniz (devletiniz) elden gider. Bir de sabredin. Çünkü Allah, sabredenlerle beraberdir." ${ }^{49}$ Kur'an'da Çekişme/Tenâzu kavramları bağlamında, "Birbirinizle çekişmeyiniz" ifadesiyle toplum birliğini sağlayan insanların kendi aralarında herhangi bir sebeple çekişmemeleri, nizalaşmamaları emredilmiştir. Nizalaşma durumunda Allah ve Resûlüne, Kur' an ve Sünnete göre hareket edilmesinin önemi vurgulanmıştır. Arabuluculuk, çekişmenin vukuu durumunda "Birbirinizle çekişmeyiniz" emrinin gerçekleşmesine yardım etmekte ve anlaşmazlığın olumlu sonuçlanmasını sağlamaktadır. Konuyla ilgili olarak aşağıdaki ayetleri de sıralayabiliriz.

1. “Eğer karı ile kocanın aralarının açılmasından endişeye düşerseniz, o vakit kendilerine erkeğin ailesinden bir hakem, kadının ailesinden bir hakem gönderin. İki taraf (arayı) düzeltmek isterlerse Allah aralarını bulur; şüphesiz Allah her şeyi bilen, her şeyden haberdar olandır." 50

$\mathrm{Bu}$ ayette bahsedilen tahkim, esas itibariyle bugünkü anlamıyla tahkim kavramını karşılamamaktadır. Zira burada tayini öngörülen hakemlerin vere-

46 Ebû Dâvûd, es-Sünen, Edeb 50.

47 Ebû Abdillah Muhâmmed b. Ahmed Ebû Bekir el-Kurtubî, el-Câmi' li ahkam'il Kur'an,tahk.: Abdullah b. Abdülmuhsin, Müessesetür-Risale, Beyrut 2006, c. 5, s. 241.

48 Kurtubî, el-Câmi' li ahkam'il Kur'an, c. 5, s. 251.

49 Enfal, 8/46.

50 Nisâ, $4 / 35$. 
ceği kararlar bir kazıyye-i muhkeme olarak tarafları bağlayıcı nitelikte değildir. ${ }^{51} \mathrm{Bu}$ özelliğiyle Kuran' da ifade edilen anlamıyla hakem, aslında birer arabulucudur. Bu ayet bağlayıcı olmamakla birlikte ihtiyari tahkime gidilebileceği yönünde açık bir hüküm olup, hâkimlik yetkisi bulunmayanların dahi karı koca arasındaki ihtilafta hakem olarak tayin edilebileceklerini belirtmiştir. $\mathrm{Bu}$ ayetten hareketle "hakemlerin" bağlayıcı olmayan kararlar verebileceğini ifade eden Kur' an "Akitler(in) gereğini yerine getiriniz." 52 âmir hükmüyle "ahde vefa" ilkesini ifade etmiştir.

Yukardaki iki ayet birlikte değerlendirildiğinde, hakem tayinine karar veren kişilerin verilen hakem kararlarına da uyması gerektiği yönünde bir anlayış gelişmiş ve bu şekilde hakem müessesesi İslâm hukukunda somut olarak ${ }^{53}$ uygulama alanı bulmuştur. ${ }^{54}$ Kavramsal çerçevede ifade ettiğimiz gibi hakemlerin ilk aşamada arabuluculuk rolleri de bulunmaktadır..$^{55}$

Karı koca arasındaki anlaşmazlıkların çözümünde hakem tayin edilen kişilerin tarafları tefrik etme ve birleştirme konularında ihtilaf bulunmaktadır. ${ }^{56}$ Katâde, Zeyd İbn Eslem, Ebû Sevr ve Dâvud hakemlerin karı ve kocayı tefrik haklarının olmadığını ancak birleştirme haklarının olduğunu belirtir. ${ }^{57}$ Çünkü tefrik, daha ileri aşama olan mahkemenin vereceği bir karardır. Buradaki hakemlerin rolü ağırlıklı olarak arabuluculuktur. İlk aşamada hakemler, uyuşmazlık çözüm sürecinin bir parçası olan arabuluculuğu gerçekleştirirler. Bu aşamada hakemler, ihtilaf konuları hangi taraftan ise, -karı ya da koca tarafından olabilir- o tarafa telkinde bulunabilir. Anlaşmazlık kadın tarafından ise "Kocasına saygılı olması, Allah'tan korkması ve güzel konuşması" istenir. Koca tarafından ise, "hanımına iyi davranması, eziyet etmemesi, nafakasını vermesi" vb. istenir. ${ }^{58}$ Hakemler birer arabulucu olarak taraflara yaklaşır ve onları bir

51 Akgündüz, “Hakem” DIAA, c.15, s.172.

52 Mâide, $5 / 1$.

53 Kurtubî, el-Câmi' li ahkam'il Kur'an, c. 6, s. 297.

54 Ayça Bozan, İslâm Hukukunda Tahkim Müessesesi, Ekim 2008, http://www.musiad.org.tr/img/yayinlarraporlar/cerceve_dergisi_48_20.

55 Cassâs, Ahkâmü'l-Kur'ân, c. 2, ss. 240-241.

56 Ebu'l-Velîd Muhammed b. Ahmed b. Rüşd, Bidâyetü'l-müctehid ve nihâyetü'l-muktasıd, Dâru'lmarife, Beyrut 1997, c.3, s.140.

57 Ebu'l-Fidâ İsmail b. Kesîr, Tefsiru'l-Kur'âni'l-azîm, Müessesetü Kurtuba, tahk.: Mustafa esSeyyid Muhammed, c. 4, s.31.

58 Ebû Ca' fer Muhammed b. Cerîr et-Taberî, Câmiu'l-beyân an te'vîli ayi'l-Kur'an, Mektebetü İbn Teymiyye, Kahire 1968, c. 13, ss. 383-385. 
araya getirmeye çalışır. Ancak taraflar isterlerse kendileri için hakem kararlarını bağlayıcı hale getirme haklarına sahiptir. ${ }^{59}$

2. “Eğer müminlerden iki zümre birbiriyle savaşırlarsa aralarını bulup barıştırın. Şayet onlardan biri diğerine karşı hâlâ tecavüz ediyorsa siz, o tecavüz edenle, Allah'ın emrine dönünceye kadar savaşın. Sonunda eğer Allah'ın emrine dönerse artık adaletle aralarını bulup barıştırın. Her işinizde adaletle hareket edin. Allah şüphesiz ki adil olanları sever. Müminler ancak kardeştirler. O halde kardeşlerinizin arasını bulup barıştırın." 60

Bu ayette kişi ya da tarafların aralarını bulmak, "adaletle aralarını bulmak", "kardeşlerin aralarını bulmak" şeklinde ifâde edilmiş ve bunun gerçekleştirilmesi, adalet anlamına gelen kıst kavramına bağlanmıştır. Allah savaşan iki grup arasında önce sulhu, aralarının bulunmasını emretmiş buna rağmen taraflardan biri hâlâ aşırı gitmeye devam ediyorsa sulh yapılamayacağını belirtmiştir. Böyle bir durumda sulh yapılması bir tarafın zulme uğraması mazlum durumuna düşmesi demektir. ${ }^{61}$

3. “Eğer bir kadın kocasının geçimsizliğinden (yatağını terk etmesinden, nafakasında ihmal göstermesinden), yahut herhangi bir suretle kendisinden yüz çevirmesinden endişe ederse anlaşma yoluyla aralarını düzeltmekte ikisine de vebal yoktur. Anlaşma daha hayırlıdır." ${ }^{62}$

Bu ayet erkeğin $n \ddot{u} s ̧ \hat{u} z^{\prime}$ undan bahsetmekte ${ }^{63}$ ve aralarındaki nüşûzdan dolayı anlaşmanın veya arabulucu vasıtasıyla sorunlarının çözülmesinin daha hayırlı olacağını vurgulamıştır.

Toplumun temelini oluşturan aile yuvasının dağılmaması için öncelikli olarak arabuluculuk müessesesinin çalıştırılması toplumun selameti açısından önem arz etmektedir. Mahkeme sürecine geçmeden insanlar arasında ikna yolunu benimsemek, tarafları ikna etmeğe çalışmak, Ku'an'ın da tavsiye ettiği bir

59 Hakemlerin karı kocanın tefrikine veya birlikte olmalarına karar vermeleri, tarafların vekili olduğunun göstergesidir. Kurtubî, el-Câmi' li ahkam'il Kur'an, c.6, s. 296. Hakemlerin vekil veya kadı olarak verdiği kararlar bağlayıcıdır. Hakemlerin kararlarının geçerliliği ile ilgili tartışmalar için bk. İbn Rüşd, Bidâyetü'l-müctehid, c.3, ss.140-141.

60 Hucurât, 49/9-10.

61 İbn el-Kayyim, Î'lâmü'l-muvakktîn, c. 1, s. 109.

62 Nisâ, 4/128.

63 Çıkıntı, tümsek anlamına nüşuz,"İsyan etmek, başkaldırmak, anlamlarına gelir. Eşler için sadâkati zedeleyip geçimsizliğe sebep olan davranışlar veya kadın için kocaya isyan edip başkaldırma, erkek için eşe eziyet etme anlamında kullanılan bir kavramdır. Ailede geçimsizlik odağı olma durumudur. el-Hüseyin b. Muhâmmed er- Râgıp el-İsfehâni el-Müfredât fi garibi'l-Kur'an, Kahraman Yay., İstanbul 1986, s. 751. Kadının nüşuzu için bk. Nisa, 106/34. 
metottur. "Sen kötülüğü en güzel haslet ne ise onunla sav. O zaman görürsün $\mathrm{ki}$, seninle arasında düşmanlık bulunan kimse bile sanki yakın dostun olmuştur." ${ }^{64}$ emriyle, insanların aralarını bulmak, hem sâlih ve hem de muslihûn ${ }^{65} \mathrm{dan}$ olmak müslümanın görevidir. ${ }^{66}$

Anlaşmazlıkların çözüm süreci olan arabuluculukta, arabulucu olan kişinin sahip olması gereken özellikler vardır. ${ }^{67}$ Başka bir ayette ise şöyle buyrulmaktadır. "O halde, tam müminler iseniz Allah' tan korkun, ihtilafa düşmeyip aranızı düzeltin; Allah'a ve peygamberine itaat edin." ${ }^{68}$ şeklindeki âmir hükümler arabuluculuğun Kur'an'daki hukukî dayanaklarıdır. ${ }^{69}$

\subsubsection{Sünnette}

İslâm hukukunun temel kaynaklarının ikincisi olan, sünnette baktığımızda insanlar arasını ıslah etme, diğer bir ifade ile arabuluculuğun mümkün olduğu görülecektir. Konuyla ilgili olarak Hz. Peygamber'in, aşağıda zikredeceğimiz uygulamaları bunun açık delilidir.

1. Hz. Peygamber, ihtilafa düşen tarafları barıştırmıştır. Meselâ, Kuba halkının birbirlerine taşlarla hücum ettiklerini duyunca, "Onları bize getirin, barıştıralım, aralarında sulh arabuluculuk yapalım" buyurmuştur. ${ }^{70}$

2. Hz. Peygamber, Ka'b b. Malik ile borçlusu İbn Ebî Hadred arasındaki ihtilafı, alacaklının alacağının yarısından vazgeçmesi, borçlunun da kalan yarıyı ödemesi şeklinde arabuluculuk ile sonuçlandırmıştır. ${ }^{71}$

64 Fussilet, 41/34.

65 Osmanlı hukuk uygulamalarında muslihûn arabulucular olarak ifade edilmektedir. Arabulucu bir kişi olabileceği gibi birden fazla da olabilmektedir. Bk. Z. Dörtop Abacı, “Bir Sorun Çözme Yöntemi Olarak Sulh:18. Yüzyıl Bursa Kadı Sicillerinden Örnekler ve Düşündürdükleri" Otam Dergisi, Ankara 2006, sayı: 20, ss.105-115.

66 Muhammed Hamdi Yazır, Hak Dînî Kur'an Dili, Eser Neşriyat, İstanbul 1971, c. 6, ss. 44644465 .

67 Bk. Makale Metni Arabulucunun Özellikleri

68 Enfal, 8/1.

69 Taraflar arasında adaletle hükmetmeyi emreden, haksızlığı yasaklayan Bakara, 2/188; Nisâ, 4/58; Mâide, 5/8,42; Sâd, 38/22,26 ayetleri de hem yönetici ve hakim gibi resmi görevde bulunanlara ve hem de hakem ve arabulucu olanlara hitap etmektedir. Akgündüz, “Hakem” DİA, c.15, s.172.

70 Buharî, es-Sahîh, Sulh 1.

71 Buharî, es-Sahîh, Sulh 10, 14; İbn el-Kayyim, Î'lâmü'l-muvakkı̂n, c. 1, s.107. 
3. Hâlü'l-musâlaha beyne'n-nâs olarak ifade edilen ${ }^{72}$ başka bir olay ise şöyle gerçekleşmiştir: Hz. Zübeyr ile Medine'li Humeyd arasında, birincisinin bahçesinden geçerek ikincisinin bahçesine gelen su yüzünden çıkan anlaşmazlığ 1 Hz.Peygambere arzettiler. O da bir arabulucu olarak "Zübeyr, ağaçlarını sulayınca bırak, $\mathrm{O}$ da sulasın" dedi. Humeyd bu duruma sinirlenip hiddetlenince de "Zübeyr, ağaçlarını sula havuzlardan taşıncaya kadar suyu tut" buyurdu. ${ }^{73} \mathrm{~Hz}$ Peygamber karşı taraf haksız olduğu için hak1ı olana hakkını kullanması şeklinde açıklamada bulunmuştur. ${ }^{74}$

4. Evs kabilesinden İbn Übey, Hazrecli İbn Revâha ve taraftarlarının birbirleriyle silahsız olarak sopalarla dövüşmeleri üzerine, Hz. Peygamber aralarına girerek onları barıştırmıştır. Ayrıca Ensar' dan İmran, karısını akrabalarına ziyarete göndermemesi olayında kadın tarafı ile erkeğin amcaoğulları arasında çıkan kavgada Resûlullah arabulucu göndermiş ve tarafları barıştırmıştır. ${ }^{75}$

5. Hz. Peygamber, "Pazartesi ve Perşembe günleri, Müslüman kardeşi ile arasında kin, düşmanlık ve kızgınlık bulunanlar hariç, Allah'a ortak koşmayan herkesi affetmek için Cennet kapıları açılır. Sonra Cenabı Hak şöyle buyurur: Bu iki kişi anlaşıp barışana kadar bekleyin " "76 buyurarak iki taraf arasında cereyan eden anlaşmazlıkların son bulmasının manevi boyutuna da dikkat çekmiştir.

6. Hz. Peygamber uyuşmazlık durumlarında çözüm süreçlerini çalıştırmış, bilirkişi ve arabuluculuğu farklı uygulamalarla göstererek gerçek bir örnek olmuştur. ${ }^{77}$ Ayrıca "Sizden herhangi birinize din kardeşi özür dileyip barışmak için gelirse, kabul etsin. Eğer kabul etmezse, bütün mü'minlerin etrafında toplanacağ 1 Havz-1 Kevser'e gelemez"78 buyurmuştur. Şunu hemen belirtmeliyiz ki Hz. Peygamber, tarafların güvenini sağladığından, niza konusu olan olaylar O'nun arabuluculuğunda hemen çözüm bulmuş, insanlar huzura kavuşmuştur.

72 Muhammed Tâhir b. Âşûr, İslâm Hukuk Felsefesi, çev.: Mehmet Erdoğan, Vecdi Akyüz, Rağbet Yayınları, İstanbul 2006, s. 52.

73 Buharî, es-Sahîh, Şürb 6, 7, 8.

74 Karaman, Bă̆layıcılık Bakımından Rasûlullah'ın Davranışları, s. 142.

75 Yazır, Hak Dînî Kur'an Dili, c. 6, s. 4462.

76 Müslim, el-Câmiu's-sahîh, el-Birr ve's-Sıla 11.

77 Hamidullah, İslâm Peygamberi, c. 2, s. 936.

78 Hâkim Nisâbûrî, el-Müstedrek, c. 4, s. 154. 
7. Hacerül-Esved'in Kâbe'ye yerleştirilmesi aşamasına tarih şahitlik etmiştir: Olay kısaca şöyle gerçekleşmiştir. Kâbe' nin onarımından sonra sıra Hacerü'l-Esved'in yerleştirilmesine gelmişti. Kabile halinde yaşayan o günkü toplumun ileri gelenleri bu şerefe nail olmak isterler ve aralarında anlaşamazlar. Hz. Peygamberden bu anlaşmazlığ 1 çözmesini isterler. Çünkü onun haksızlık yapmayacağından herkes emindir. Hz Peygamber'e durumu açılarlar. Bunun üzerine Hz. Peygamber hırkasını çıkarır yere serer. Hacerü'l-Esved taşının, üzerine konulmasını ister. Taş hırka üzerine konulur ve her kabile lideri hurkadan tutarak Kâbe'deki yerine yerleştirilir. ${ }^{79}$ Böylece taraflar arasındaki anlaşmazlık sona erer.

8. Hz. Ümmü Seleme'nin rivayetine göre, Hz. Peygambere eski bir miras dâvasını çözmek üzere iki kişi müracaat eder. Dâvayı çözecek delilleri olmayınca Efendimiz, "Siz bana gelip dâva açıyorsunuz. Ben de bir beşerim. Belki sizin bazınız bazınızdan daha düzgün ve beliğ bir şekilde ifadede bulunabilir. Ben de işittiğime göre hüküm veririm. Şunu iyi biliniz ki, zahir delillere istinaden kime hakkı olmadığı halde kardeşinin hakkını vermiş olursam, o, bunu almasın. Zîra bu durumda ben ona Cehennem'den bir ateş parçası vermiş olurum" diye açılamada bulununca, iki adam da ağlayarak “Benim hakkım kardeşimin olsun!" der. Hz. Peygamber de, “Madem böyle diyorsunuz, o zaman gidip malı taksim ediniz. Sonra hakkı araştırınız. Bundan sonra da kura ile kendi payınıza düşeni belirleyip helâlleşiniz!" 80 buyurarak ihtilafları çözüme kavuştururken, tarafların, birbirlerinin haklarına riâyet etmesi gerektiğini ayrıca vurgulamış ve dikkat çekmiştir.

9. Cabir b. Abdillah'ın müracaatı üzerine, babasından alacağı olan kişilerle onun arasında Hz. Peygamber' in arabuluculuk yapıp helâlleşmelerini sağlaması da ${ }^{81}$ arabuluculuğun önemini gösteren diğer bir delildir.

10. “Haramı helâl yahut helâlı haram yapan çeşidi hariç, Müslümanlar arasında sulh arabuluculuk ${ }^{82}$ caizdir" hadis-i şerifi de caiz olmayan arabuluculuk

79 Ebû Abdillah Muhammed İbn Sa'd, et-Tabakâtü'l-Kübrâ, Beyrut 1985, c. 1, ss. 145-147; Ebû Muhammed Abdulmelik b. Hişâm, es-Sîretü'n-nebeviyye, tahk.: Mustafa es-Sakka, Kahire 1955, c. 1, ss. 192-197.

80 Ebû Dâvûd, es-Sünen, Akdiye 7; Şemsüddîn Ebî Abdillah Muhammed İbn el-Kayyim elCevziyye (ö.751/1350), et-Turuku'l-hukmiyye fis-siyâseti'ş-şsr'iyye, Mektebetü Dâri'l-Beyan, Beyrut 1989, s. 246.

81 Buharî, es-Sahîh, Sulh 12.

82 Hadiste geçen ve genel kavram olan sulh kelimesi, arabuluculuğu da kapsadığından arabulu- 
için değişmez bir ölçü koymuştur. ${ }^{83} \mathrm{Bu}$ anlamda İslâm hukukçuları arabuluculuğu haram ve helal olan arabuluculuk olmak üzere iki kısımda incelemişlerdir. Haram olan arabuluculuk, helali haram yapma, yapılması farz olan bir yükümlülüğü düşürme, faiz alıp yeme şeklindeki arabuluculuk örnekleridir. Bu şekilde yapılan uyuşmazlık çözüm yolları kabul edilemez. Helal olan arabuluculuk ise Allah'ın rizasına dayanan ve hasmeynin de gönüllü olarak kabul ettiği sulh arabuluculuktur. ${ }^{84}$ Bu şekilde yapılan arabuluculuk en adil ve doğru bilgiye sahip muslih tarafından yapılmakta, ıslâhu zâti'l-beyn olan arabuluculukla insanların arasını düzelterek fesadı gidermenin bir ibadet olduğu belirtilmektedir. ${ }^{85}$

11. İnsanlar arasında arabulucu olarak barışı sağlama ile ilgili Hz. Peygamber'den pek çok hadis rivâyet edilmiştir. "Size oruç, namaz, hac ve sadakanın derecesinden daha faziletlisini söyleyeyim mi?" "Evet yâ Resûlellah" denilince Hz. Peygamber şöyle buyurmuştur: "Kişilerin arasını bulup barıştırmak (ıslâhu zâti'l-beyn)." 86

Hz. Peygamber bu konuya o kadar önem vermiştir ki sadece ıslahı kastederek insanların aralarını bulup barıştırmak için yalan söylenebileceğini belirtmiştir. ${ }^{87}$

\subsubsection{Sahabe Uygulamalarında}

Allah Resûlü'nden sonra O'nun Raşid Halifeleri de aynı yolu takip ederek Müslümanları, mahkemeden önce arabuluculuğa teşvik etmişlerdir. Nitekim Hz. Ömer'in Kûfe kadısı Ebu Musa el-Eş'ari'ye gönderdiği kaza (yargı) talimatnamesinde, "Hasımları arabuluculuk yapmaya yönlendirin. Çünkü davaların mahkeme kararıyla hükme bağlanması onlar arasında düşmanlık meydana getirir."; "İnsanlar arasında helâlı haram, haramı helâl etmemek şartıyla sulh/sslah, arabuluculuk caizdir" 88 buyurmuş, Hz. Osman da çoğu yargılamaları-

culuğa dikkat çektik.

83 Tirmîzî, es-Sünen, Ahkâm 17; Ebû Dâvûd, es-Sünen, Akdiye 12.

84 İbn el-Kayyim, I'lâmü'l-muvakkînn, c. 1, s. 109; Mâverdî, el-Hâvi'l-kebîr, c. 6, s. 367.

85 İbn el-Kayyim, I'lâmü'l-muvakkî̂n, c.1, s. 110.

86 Ebû Dâvud, es-Sünen, Edeb 50.

87 Yalanın söylenebileceği üç yer için bk. Müslim, es-Sünen, Birr 101; Ebû Dâvud, es-Sünen, Edeb 50 .

88 Serahsî, Mebsut, c. 20, s.134, c. 16, ss. 61-62; İbn el-Kayyim, I'lâmü'l-muvakkîn, c.1, s. 85 vd.; Mecelle, Md. 1826; Muhâmmed Hamidullah, el-Vesâiku's-siyâsiyyetü li'l-ahdin-Nebevîyyi ve'l- 
nı sulh şeklinde gerçekleştirmiştir. ${ }^{89}$

Hz. Ali ile Muaviye arasındaki ihtilâfta, Muaviye'nin; iki tarafın birer hakem tayin ederek, hakemlerin ihtilâfı hükme bağlaması teklifinin Hz. Ali tarafından kabul edilmesi ve Ali'nin “Ebu Musa el-Eş'ari”yi, Muaviye'nin de “Amr İbnü'l-As" 1 hakem tayin etmesi ve aralarında "Tahkimname"90 imzalamaları, tahkimle arabuluculuğun ortaya çıkmasıdır. Ayrıca tahkim konusunda sahabenin icma ettiği İslâm hukukçuları tarafından belirtilmiştir. ${ }^{91}$ Hakemlerin ilk aşamada arabulucu rolünde olmalari ${ }^{92}$ birden fazla arabulucu olabileceğinin de bir göstergesidir.

\subsection{Arabulucunun Ehliyeti}

Genel anlamda ve ahlâkî olarak arabulucu ve muslih olma, her müslümanın yerine getirmesi gereken bir görevdir. Ancak kul hakların ilgilendiren ve yargıya başvurmayı gerektiren konularda arabuluculuk yapan kimsenin hukuk bilgisine sahip olması gerekir. Örneğin boşanma aşamasına gelmiş eşlerin arasının bulunmasını ancak eğitim almış hukukçu sağlayabilir. Mahkemeye intikal etmiş bir davanın sonuçlanmadan, hâkim tarafından arabulucuya yönlendirilmesi durumunda bu arabulucunun sahip olması gereken şartların önemi ortaya çıkmaktadır. Genel olarak hâkimde bulunan şartların hakemde de bulunması gerektiğini ifade eden İslâm hukukçuları, uzlaşmayı sağlayan kişilerin gerçekleştirdiği görevlere göre, belirli şartlara sahip olması gerektiği görüşündedirler. ${ }^{93}$ Yargıya yardımcı olacak arabulucuların, hukuk eğitimi almış, iletişim

hilâfeti'r-râşide, Daru'n-Nefâis, Beyrut 1985, s. 428.

89 Mâverdî, el-Hâvi'l-kebîr, c. 6, s.366.

90 Bu “Tahkimname“de özetle şunlar yazılıdır:"Bismillahirrahmanirrahim. Bu vesika, Ali b. Eb̂̂ Talib ile Muaviye b. Ebî Süfyan arasında bir kararnamedir. Ali, Irak Halkı ve müttefikleri için; Muaviye, Şam Halkı ve müttefikleri için Allah'ın hükmü ve Kitabına razı olarak Allah'ın Kitabının ihya ve imha ettiğini imha etmek ve aralarında sadece Allah'ın Kitabını hakem kılmak üzere taahhüt etmişlerdir. Hakemler - ki bunlar, Ebû Musa el-Eş'ari ile Amr b. As'dırKur'an'1 Kerîm'de buldukları ahkâm ile hüküm verecekler, Kur'an'1 Kerîm' de bulamadıkları takdirde Resulullah'ın birleştirici olan sünnetine başvuracaklar ve onunla hükmedeceklerdir." Hasan H. İbrahim, İslâm Tarihi, 2. Baskı, Kayıhan Yay., İstanbul 1987, c. 2, s. 46; İsmail Yiğit,"Sıffîn Savaşı", DİA, İstanbul 2009,c.37,s.108.

91 Zeylâî, Tebyînu'l-hakâik, c.5, s.117.

92 Ateş, Kur'an Ansiklopedisi, c.3, ss.146-148.

93 Mavsılî, Kitâbu'l-ihtiyar, c. 2, s.111; Tarablûsî, Muînu'l-hükkâm, s. 27; Akgündüz, "Hakem" DIA, c.15, s.172. 
becerilerine sahip kişilerden olmas ${ }^{94}$ bunun açık göstergesidir. Çünkü anlaşmazlık ve hak ihlallerini sona erdirmek belli şartları haiz olmayı gerektirir. Bu şartlar şunlardır:

\subsubsection{Müslüman Olması}

Müslümanlar arasında vuku bulan uyuşmazlık ve hak ihlallerinin adalete uygun sonuçlandırılmasında, uyuşmazlık çözüm yöntemlerini kullanan kişilerin Müslüman olması şartında İslâm hukukçuları görüş birliği içerisindedir. Buna göre Müslüman olmayan birisinin Müslümanların davalarına bakması caiz olmamaktadır. ${ }^{95}$ Arabulucunun Müslüman olması, çözümün İslâm'a uygun olması gerekliliğinden dolayıdır.

\subsubsection{Edâ Ehliyetine Sahip Olması}

Edâ ehliyeti, insanın hukuka uygun olarak fiil ve muamelelerde bulunabilme kudret ve selâhiyetidir. ${ }^{96}$ Edâ ehliyeti zimmetle birlikte akil bâliğ olmaya bağl1dır. ${ }^{97}$ Arabulucunun akil bâliğ olması, edâ ehliyetine sahip olması gerekir. Çünkü kendi hak ve ehliyetini kullanamayan bir kişi, diğer insanların ihtilaflarını çözerek anlaşmayı sağlayamaz. Deli ve bunak olan kimsenin nasıl hâkim olması câiz değilse arabulucu olan kişinin de deli ve bunak olması câiz değildir. Eda ehliyetinin tamamlayıcısı bağlamında ayrıca arabulucu zekâ ve ferasetiyle tarafların arasını bulurken, gafletten uzak, uyanık olması, ârifü'l-hak olması gerekir. ${ }^{98}$

\subsubsection{Adâlet}

Adâlet şartından maksat, insanlar arasında davalara bakan kişilerin dînî konularda daha duyarlı, haramlardan, şüphelerden kaçınan, emânet ehli ve şâhitlik yapabilme vasıflarına sahip olması demektir. Bunlar İslâm hukukçularının

\footnotetext{
94 Tanrıver, "Alternatif Uyuşmazlık Çözüm Yolları", s. 165.

95 Ebû'l-Hasan Ali b. Muhammed b. Habîb el-Mâverdî, el-Ahkâmu's-sultâniyye ve'l-velâyâtu'ddîniyye, Dâru'l-Kütübi'l-İlmiyye, Beyrut ty. s. 84; Şîrâzi, el-Mühezzeb, c. 3, s. 593.

96 Abdulkerim Zeydân, el-Veciz fi usuli'l-fikh, Dersaadet, İstanbul ty. s. 93; Fahreddin Atar, Fikıh Usûlü, MÜiF.Yay., İstanbul 1992, s. 144.

97 Şîâazi, el-Mühezzeb, c. 3, s. 593

98 Mâverdî, el-Ahkâmu's-sultâniyye, s. 83; Şîrâzi, el-Mühezzeb, c. 3, s. 593.
} 
aradığı vasıflardır. ${ }^{99}$ Arabulucu olan kişinin de bu özelliklerde olması güven ortamının oluşmasında ve tarafların arabulucuya itibar etmelerinde önemlidir. Adâlet sahibi olmayan kişinin tarafları yanıltması kuvvetle muhtemeldir.

\subsubsection{Bedenen Sağlam ve Sıhhatli Olması}

İslâm hukukçuları tarafından davalara bakan kişilerde aranan bu şartın, yargılama aşamasına yardım eden arabulucuda olmaması düşünülemez. Nitekim daha önce geçtiği gibi hâkimde aranan şartların hakemde de olması gerektiği, İslâm hukukçuları tarafından belirtilmiştir. ${ }^{100}$ Dolaysıyla bu şartın arabulucuda da olması beklenir. Çünkü arabulucu olan kişinin hak ve bâtılı ayırmak için gerekli olan görme, konuşma, işitme gibi özelliklerinin tam olmasi ${ }^{101}$ taraflar arasında iletişimi sağlamada zorunludur.

\subsubsection{Hukuk Bilgisi}

Tarafların ihtilaflarını çözme konumunda olan kişilerin hukuk bilgisinden kastedilen Kur'an'in ve Sünnetin bilinmesi, ${ }^{102}$ yargilamanın, Hz. Peygamber'in uygulamalarının değişen ve gelişen şartlara göre örnek alınmasıdır. Uyuşmazlık sürecinin bir parçası olan arabuluculukta da hukuk bilgisi ${ }^{103}$ önemli ve gereklidir. Hukuk bilgisi olmayanın, hüküm vermesi câiz değildir. ${ }^{104}$ Arabulucu olan kişinin, mümkünse ictihad yeteneğine sahip bilgili birisinin olması iyidir. ${ }^{105} \mathrm{Bu}$ vasfı taşıyan kişi bulunamadığı takdirde, arabulucunun en az uyuşmazlıkları gidermede yeterli hukuk bilgisi olan biri olması gerekir. Çünkü arabulucu tarafların arasını bulmada ve adâleti sağlamada meslekî bilgisiyle önemli

99 Mâverdî, el-Ahkâmu's-sultâniyye, s. 84; Şîrâzi, el-Mühezzeb, c. 3, s. 593.

100 Tarablûsî, Muînu'l-hükkâm, s.27; Mavsılî, Kitâbu'l-ihtiyar, c. 2, s.111.

101 Mâverdî, el-Ahkâmu's-sultâniyye, s. 84.

102 Mâverdî, el-Ahkâmu's-sultâniyye, ss. 84-85; Serahsî, Mebsut, c. 16, s. 162; Mavsılî, Kitâbu'lihtiyar, c. 2, ss. 98-99.

103 İbn el-Kayyim, I'lâmü'l-muvakkı̂̂n, c. 1, s. 109.

104 Şîrâzi, el-Mühezzeb, c. 3, s. 593; Mâverdî, el-Ahkâmu's-sultâniyye, s. 84.

105 Hz Peygamber Muaz b. Cebel'e: "Önüne bir uyuşmazlık geldiğinde ne ile hükmedeceksin?” Sorusuna “Allah'ın Kitabında olanlarla."Sonra “Allah'ın Kitabında yoksa?” "Allah Resûlünün Sünneti ile." Sonra "Allah Resûlünün Sünnetinde de yoksa?" sorusuna ise "İçtihad ederim" diyerek cevap vermesi uyuşmazlık konularını çözme konumunda olanların da bu bilgilere sahip olması gerektiğini göstermektedir. Bk. Abdulvahhab Hallâf, İlmu usĥli'l-fikh, Edâ Neşriyat, İstanbul 1991, s. 21-22. 
fonksiyona sahiptir. ${ }^{106}$

\subsubsection{Güvenilir ${ }^{107}$ ve Objektif Olması}

Arabulucu tarafların güvenini kazanan bir kişidir. Nitekim arabulucu, anlaşmazlık ve niza konusunu çözerken tarafların güvenini kazandığından dolayı arabulucu olmuştur. Arabulucu bu güveni sarsmamak için de söz konusu olayın çözümünde objektif olmalı ${ }^{108}$ taraflara aynı mesafede bulunmalıdır. ${ }^{109}$

Arabulucu her yönüyle güvenilir ve adaletli olarak tarafları ikna etmeye çalışır. Hz. Peygamberin arabulucu olarak istenmesi hiç şüphesiz onun güvenilir olması ve o günkü toplumda O'nun haksızlık etmeyeceğine olan güvenin tam olmasından kaynaklanmaktadır. Hz. Peygamber, peygamber olmadan önce bile "Muhammedü'l-Emin" ismiyle çağrılmış insanlara her yönüyle örnek olmuştur. Bu durum Kur'an'ı Kerim'de “O müminler için en güzel örnektir"110 şeklinde ifade edilmiştir.

\subsection{7. İkna Kabiliyetine Sahip Olması}

Arabulucunun ikna kabiliyetine sahip olması ${ }^{111}$ tarafların ihtilaflarını çözmede önemli bir etkendir. “İyilikle kötülük bir olmaz. Kötülüğü en güzel bir şekilde sav." 112 ifadesi ikna esasının temelini oluşturur. Toplumu temelden sarsma özelliği olan uyuşmazlıkların çözümü hiç şüphesiz duyguları anlayabilme ve ikna kabiliyetine sahip olma ile mümkündür. Taraflara yumuşak davranamayan onları anlayamayan arabulucu olamaz. Arabulucu olmak, taraflarla iletişim kurmayı ve onları anlamayı gerektirir. Hz peygamber de bu özelliği ile tarafları ikna etmeye çalışmıştır. ${ }^{113}$

106 Tanrıver, "Alternatif Uyuşmazlık Çözüm Yolları”, s. 170. Günümüzde arabulucu olabilmek için lisans mezunu olanların en az 100 saatlik arabuluculuk hukuk eğitimi almaları gerekmektedir. http://www.kgm.adalet.gov.tr/tbmmkom/arabuluculuk.pdf (erişim tarihi: 30.09.2012).

107 Mavsılî, Kitâbu'l-ihtiyar, c. 2, s. 98.

108 Tanrıver, "Alternatif Uyuşmazlık Çözüm Yolları”, s. 165.

109 Kurtubî, el-Câmi' li ahkam'il Kur'an, c. 6, s. 290.

110 Ahzab, 33/21.

111 Tanrıver, "Alternatif Uyuşmazlık Çözüm Yolları", s. 166.

112 Fussilet, 43/34.

113 Abdullah Özbek, Bir Eğitimci Olarak Hz. Muhammed, Esra Yay., Konya 1991, s. 132. 


\subsubsection{Sabırlı ve Dikkatli Olması}

Arabulucu her iki tarafı sabırla dinlemeli, aktif dinleme yöntemini kullanmalı, dikkatli davranarak tarafların sorununu çözmeye çalışmalıdır. Arabuluculuk, sorun odaklı olmayı, taraflar arasında empati ${ }^{114}$ ve iletişimi sağlamayı, görüş ayrılıklarının yeterince tartışılarak çıkarların dengelenmesini gerekli kıldığından bu süreçte arabulucunun sabırlı ve dikkatli olması son derece önemlidir. Arabulucu iyi niyet sergileyen, açık anlaşılabilen bir dil kullanabilen, karar verme yöntemlerini bilen ${ }^{115}$ kişiler olarak iletişim kurabilmesi, çözüm konusuna odaklanabilmesi, gereksiz konuları dışarıda bırakabilme becerisine sahip olması ve sonuçta hâkimin iş yükünü azaltmaya yardımcı olması sabır ve farkındalıkla mümkündür.

Arabulucunun önerileri nihai karar olmadığından, tarafların önerileri ve memnuniyetleri esastır. Önemli olan ortak noktaya gelebilmeyi sağlamaktır. Arabulucu, sabır ve dikkatiyle, bütün bu süreçlerde, aşama aşama kolaydan zora doğru bir yol takip ederek tarafların çıkmaza girmeleri durumunda çözüm formülleri ortaya koyup bu formüller etrafında sorunu gidermelidir.

\subsection{Arabuluculuğun İşlev Alanı}

Arabuluculuk, helali haram, haramı helal yapmadıkça ${ }^{116}$ kul haklarının bulunduğu alanlarda geçerlidir. ${ }^{117}$ Eğer ihtilaf konusunda bir uzlaşma sağlanacaksa bu alan, Allah hakları veya Allah haklarının baskın olduğu kul hakları olmamalıdır. Kul haklarında uzlaşmanın gerçekleşebilmesi için söz konusu hakkın uzlaşan tarafa ait olması, üzerinde istediği gibi tasarrufta bulunabilmesi, hakka karşılık bedel alması ve bu hakkın belirli olması gerekir. ${ }^{118}$

İslâm hukukçuları hakları farklı açılardan tasnif edilmiştir. Hakkın mahiyeti ve sağladığı yararlar açısından özel ve genel olmasından dolayı, Allah'a izafe edilen haklar Allah hakları ve kullara izafe edilen haklar ise kul hakları adıyla ayrı-

114 Empati diğer kişinin psikolojik durumunu anlama ve içsel yaşantısını paylaşma demektir. Bk. Necla Acun, Kişiler Arası İlişkiler ve İletişimde Empati, Alim Kaya(edit.), Pegem Akademi, Ankara 2010, s.125.

115 Şîrâzi, el-Mühezzeb, c. 3, s. 593.

116 Tirmîzî, es-Sünen, Ahkâm 17; Ebû Dâvûd, es-Sünen, Akdiye 12.

117 Karafî, ez-Zehîra, , c. 5, ss. 336-344; Avdeh, et-Teşri'u'l-cinâi'l-islâmî, c. 2, s. 158; Dağcl, İslâm Ceza Hukukunda Şahıslara Karşı Müessir Fiiller, s. 124; Yaylalı, İslâm Hukukunda Sulh, s. 145.

118 Mahmûd Mahcûb Abdunnûr, es-Sulh, ss.109-117; Nezih Hammad, Akdü's-sulh, ss.38-47. 
ma tabi tutulmuştur. Ayrica her ikisinin müşterek olduğu haklar, Allah veya kul haklarının galip geldiği haklar şeklinde çeşitleri de bulunmaktadır. ${ }^{119}$

Allah hakları denildiğinde, iman ve ibadetleri içeren sadece Allah'a mahsus olan, belirli bir kişi veya zümreye ait olmayan kamu yararını ifade eden haklar anlaşılır. Allah haklarının özelliği arabuluculuk, af veya sulh gibi yollarla ıskâtı câiz olmamakla beraber değiştirilmesi ortadan kaldırılması da câiz değildir. ${ }^{120}$

Kul hakları ise, tamamıla ferde ait olan maslahat ve menfaatlerdir. Borç, diyet, gibi malî haklar, kişiye özel haklardır ki sahibi, kötüye kullanmamak kaydıyla dilediği şekilde tasarruf edebilir. ${ }^{121}$ Dolaysıyla alacağından vazgeçmesi, bir bedelle sulh olması, affetmesi kişinin iradesine bağlıdır.

Kısas gibi kul haklarının daha fazla olduğu alanlarda da haklardan vazgeçmek mümkündür. Örneğin; Allah'a ait olan kısmı saklı kalmak üzere, mağdurun mirasçısı kâtili affedebileceği gibi kâtilden tazminat alarak uzlaşabilirler. ${ }^{122}$ Arabulucu da ancak kulun haklarına taallûk eden alanlarda faaliyette bulunarak sulh akdinin meydana gelmesine yardım eder.

Arabuluculuk, kul haklarını ilgilendiren, eşler arasındaki anlaşmazlıklardan işçi işveren arasındaki uyuşmazlıklara, devletlerarası hukuktan, İslâm ceza hukukuna kadar her alanda uygulanma imkânına sahiptir.

\subsection{Arabuluculuğun İşleyişi}

Arabuluculuk ihtilaflı tarafların isteği üzerine sorunlarını çözmek için bir üçüncü kişiye müracaat etmeleriyle başlar. Arabulucu, tarafları ihtilaf konusunu çözmek üzere ilk toplantıya davet eder veya taraflar arabulucuya gelerek süreci başlatırlar. Bu toplantıda taraflar nasıl bir usul takip edeceklerini kararlaştırırlar. Tarafların güvenini kazanan Arabulucu da bu usule göre arabuluculuk faaliyetini yürütür.

Arabulucu, hem tarafların birbirini tanıması hem de kendisinin tarafları tanıması hususunda gerekli özeni gösterir. Daha sonra uyuşmazlık konusuna

119 Serahsî, Usûl, Dâru'1-Kütübi'l-İlmiyye, Beyrut 1993, c. 2, s. 289; Zeydân, el-Veciz, ss. 82-86; Ali Bardakoğlu, "Hak”, DİA, İstanbul 1997, c. 15, ss.142-143.

120 İbn el-Kayyim, I'lâmü'l-muvakkî̂n, c. 1, s. 108; Ali Bardakoğlu, “Hak”, DİA, c. 15, ss.142-143.

121 Zeydân, el-Veciz, ss. 82-86; Ali Bardakoğlu, “Hak”, DİA, c. 15, ss.142-143.

122 Zeydân, el-Veciz, ss. 82-86. 
geçerek tarafları dinler ${ }^{123}$ ve ortak noktada buluşturmaya gayret eder. Arabulucu hâkim konumunda olmadığının bilincinde olarak, söz konusu uyuşmazlığın olumlu ve olumsuz yönlerini vurgulayarak çözüme ulaşmaya çalışır. Aksi kararlaştırılmadıkça, taraflardan her biri arabuluculuk müzakerelerine bizzat katılır.

Sorunları çözme noktasında Hz. Peygamber'in, arabuluculuğun nasıl olması gerektiği ve kullandığı metotlara daha önce verdiğimiz örnekler de düşünüldügünde arabuluculuğun işleyişi ortaya çıkacaktır.

Hz. Peygamber önce tarafların niza konusunu yeterince tetkik etmiş, yerine göre arabulucu ve hakem olarak, sorunun çözüm yolunu uygulamasıla taraflara göstermiş ve taraflar ikna olarak sonuçtan memnun olmuştur.

Arabuluculuğun işleyişi nizâ konusunun giderilmesiyle ${ }^{124}$ son bulur. Yukarıda geçtiği gibi Hz. Peygamber de kendi hayatında bu işleyişs sürecini gerçekleştirmiş, birçok konuda arabulucu rolünde bulunmuş uyuşmazlık konusu olan davaları olumlu olarak sonuçlandırmıştır.

\subsection{Arabulucunun Görevleri}

Gerekli özelliklere sahip olan arabulucu yargıya bağlı olarak görev yapabileceği gibi, tarafların belirlemesi ve kendisinin de kabul etmesiyle de bu görevini gerçekleştirebilir. İhtilaf konusu yargı aşamasında ise arabulucu, tarafların belirlediği süre içerisinde uzlaşmalarını sağladığı takdirde, durumu mahkemeye bildirerek resmîleștirir. Arabuluculuk görevi, tarafların arabulucuyu azletmeleriyle, arabulucunun bu görevden ayrılmasıyla veya ölümüyle sona erer. Hakemlerde de görevin sona ermesi arabuluculukta olduğu gibidir. ${ }^{125}$

Arabuluculuk sürecinde tarafların birbirini anlamaları kısaca iyi bir iletişimin sağlanması gerekir. Arabuluculukta karşılıklı güvenin oluşması ancak tarafların mesajlarının iyi anlaşılmasıyla mümkün hale gelir. Birbirini anlayan taraflar sorunları daha çabuk çözer. Arabulucunun öncelikle taraflar arasındaki iletişimi iyi sağlaması önem arz etmektedir. Arabulucu tarafların ortak noktala-

$123 \mathrm{~Hz}$ Peygamber'in Hz Ali'ye “Davalı iki şahıs önüne oturduğunda birincisini dinlediğin gibi, ikincisini de dinlemeden aralarında hüküm verme" buyurması tarafların tanınması ve eşit davranılması açısından önemlidir. Bk. Tirmîzî, es-Sünen, Ahkâm 5.

124 Ebû Muhammed Mahmud b. Ahmed el-Aynî, el-Binâye fî şerhi'l-hidâye, Daru'l Fikr, Beyrut 1990 , c. 9 , s. 3,5

125 Burhanuddin İbrahim b. Ali b. Ebi'l-Kasım b. Muhammed İbn Ferhûn, Tabsiratü'l-hukkâm fî usûli'l-akdiye ve menâhicu'l-ahkâm, Misır 1301, c. 1, s. 78. 
rını öne çıkararak asgari müştereklerde birleşmesini sağlar. Taraflar kendilerini birbirinin yerine koyarak empati kurmalıdırlar. Bu süreçte, İslâm Hukukunun önemle üzerinde durduğu arabuluculuğun ahlâkî yönü de göz önünde bulundurulmalıdır. Çünkü Hz. Peygamber "Mümin müminin aynasıdır"126 ifadesiyle iletişime dikkat çekmiş, sahabeye iletişim bağının oluşmasının ancak selamlaşma ile mümkün olacağını açıklamıştır. Kur'an-1 Kerim'de selam verilmesi ${ }^{127}$ ve selâma en güzel şekilde karşılık verilmesi ${ }^{128}$ emredilmiştir. Yine Kur'an-1 Kerimde tokalaşmak safh kökünden bir kavram olarak, hoşgörü ve affedicilik ${ }^{129}$ anlamında kullanılır ki tarafların birbirini affedici ve hoşgörülü olmalarını, birbirini sevmelerini ifade eder. Hoşgörü İslâm Hukukunun özelliklerinden biri ve gerçekleştirmek istediği gayelerin en önemlilerindendir. ${ }^{130} \mathrm{~Hz}$ Peygamber de "Birbiriyle karşılaştığında tokalaşan iki müslüman oradan ayrılmadan hataları affedilir." 131 buyurmuştur. Taraflar arasında arabuluculuk için bu ilkeler önemlidir. Ayrıca taraflar birbirlerinden ayrılmadan diyalog kurup, ortak noktaya gelmelerini sağlamak arabulucunun görevidir. Bununla ilgili olarak Kur'an-1 Kerimde Allah "Bir topluluk diğger bir toplulukla alay etmesin; olur ki onlar kendilerinden daha hayırl olabilir" 132 buyrulmaktadır. Tarafların birbirlerine saygılı olmaları elzemdir. Ancak niza konusundan dolayı birbirine kinli olabilirler. Bu bağlamda arabulucunun tarafların insan olarak eşit olduğunu her şeyin sahibinin yüce Allah olduğunu ifade ederek tarafları düşündürmesi önemli olmaktadır. Tarafların birbirini anlaması için etkin dinleme ${ }^{133}$ doğrultusunda taraflar yönlendirilirken arabulucu tarafından "seni anlıyorum, seni dinliyorum" mesajı verilerek taraflara değer verildiği ifade edilmeli ve güven ortamı geliştirilmelidir. Arabuluculuk bu ortamın oluşturulmasını sağlayan kompleks bir süreç olarak tezahür etmektedir. Bu süreçte tarafların kendi başlarına oluşturamadığ güven ortamı, arabulucunun devreye girmesiyle gerçekleştirilir.

126 Ebû Dâvûd, es-Sünen, Edeb 49.

127 Nur, 24/27.

128 Nisa, $4 / 86$.

129 Bakara, 2/109; Hicr, 15/85; Zuhruf, 43/79.

130 Tâhir b. Âşûr, İslâm Hukuk Felsefesi, s. 88.

131 Ebû Dâvûd, es-Sünen, Edeb 142.

132 Hucurât, 49/11.

133 Kişilerarası çatışma çözmede kullanılan, empatik dinleme olarak da ifade edilen geri iletim kullanılarak yapılan dinlemedir. Daha geniş bilgi için bk. Zeynep Cihangir, Kişilerarası İlişkiler ve İletişimde Dinleme, Alim Kaya(edit.), Pegem Akademi, Ankara 2010, s. 109. 


\subsection{Arabuluculuğun Günümüz Hukuk Sistemlerinde Uygulanışı}

Arabuluculuğun günümüz dünyasındaki uygulanışı üzerinde kısaca durmanın faydalı olacağını düşünüyoruz. İlk olarak Anglosakson hukuk ${ }^{134}$ menşeili olarak alternatif uyuşmazlık çözüm yolları arasında ifade edilen ${ }^{135}$ arabuluculuk ABD de 1964 yılında "Topluluk İlişkileri Servisi” (Community Relations Service)adıyla kurulmuş ve bu kurumda arabuluculuk faaliyetleri yürütülmüştür. 1960'l y yllarda (Neighborhood justice Centers) adıyla yerel adalet merkezleri kurularak bu sayede bireyler arasındaki ihtilaf ve uyuşmazlıkların yerinde çözüm bulması için faaliyet gösterilmiştir. 1980'li yıllardan itibaren de bu merkezler adalet sisteminin bir parçası haline getirilmiştir. ${ }^{136}$

Batı Avrupa ülkeleri İngiltere ve Norveç'te arabuluculuk, uyuşmazlıkların çözümünde kullanılmaktadır. Yine Doğu Avrupa ülkelerinde de arabuluculuk 1990'lı yıllardan itibaren birçok alanda çözüm yolu olarak değerlendirilmekte ve gelişmektedir. Orta doğu, Afrika ve Latin Amerika ülkelerinde ise bu konuda nadiren kurumsallaşma gözlenmekte ve toplum içerisinde belli derecede saygınlık kazanmış kişiler tarafından yürütülmektedir. Arabuluculuğun profesyonel anlamda gerçekleştirildiği Japonya, Endonezya ve Arjantin gibi ülkeler de bulunmaktadır. ${ }^{137}$

Ülkemizde ise, iş uyuşmazlıklarında dört yıllık hukuk eğitimi almış, iş ve işveren ilişkilerinde en az on yıl deneyimli, her hangi bir sendikaya üye olmayan, medenî haklarını kullanma ehliyetine sahip, ücretli resmi arabulucular

134 Anglosakson hukuk sistemi, 11. yüzyılda gelişmiş, İngiltere, Amerika, Kanada, gibi ülkelerde uygulanmaktadır. Bu sistemde hukuk tedvin edilmemiştir. Hukuk, örf ve adet kuralları ve çok sayıda mahkeme kararı ve dağınık halde bulunan çeşitli kanunlardan oluşur. Bu sistemde içtihat hukukun bir kaynağıdır. İçtihat örnek alınan mahkeme kararı demektir. Anglosakson sisteminde bir mahkemenin vermiş olduğu bir karar, ifade ettiği ilke veya kural, hukuk kaynağı olarak kabul edilmektedir. Kamu hukuku-özel hukuk ayrımı yoktur. Hukuk bütün dallarıyla aynı hukuktur ve buna "common law (ortak hukuk)" denir.

http://wiki.hukuki.net/Hukuk_sistemleri

135 Diğer alternatif uyuşmazlık çözüm yolları için bk. Süha Tanrıver, "Hukuk Uyuşmazlıkları Bağlamında Alternatif Uyuşmazlık Çözüm Yolları ve Özellikle Arabuluculuk", Türkiye Barolar Birliği Dergisi, Ankara 2006, sayı: 64, ss. 151-170.

136 Bk. McGillis Daniel, Community Mediation Programs; Development and Challenges Washington: Us Department of justice, 1997; Sarah ve Bermen, Greg, Good Courts: The Case for ProblemSolving justice, New Press, Newyork 2005.

137 Moore Christopher W., The Mediation Process: Practical Strategies for Resolving conflict, San Francisco: Jossey-Bass 2003, ss. 22-32. 
bulunmaktadır. ${ }^{138}$ Ayrıca arabuluculukla ilgili yasal düzenleme çalışmaları devam etmektedir. ${ }^{139}$ Uyuşmazlık ve ihtilafların çözümünde arabuluculuk mahkemelere yardımcı olma, sorunları yerinde halletme açısından önemlidir. Arabuluculuk kurumunun canlandırılması mahkemelere gelen davaların azalmasına ve sorunsuz bir toplum oluşturmaya katkı sağlayacaktır. Arabuluculuk sayesinde davalaşan insanlar sonuçtan memnun olacaklarından bu uygulama toplumda olumlu karşılanacaktır.

\section{Sonuç}

Arabuluculuk ahlâkî olmakla birlikte aynı zamanda hukukî bir işlemdir. Eşler arasındaki anlaşmazlıklardan işçi işveren arasındaki uyuşmazlıklara, İslâm Aile Hukukundan İslâm Borçlar Hukukuna, Devletlerarası hukuktan, kul haklarını ilgilendiren İslâm Ceza hukukuna kadar her alanda uygulama özelliğine sahiptir.

İslâm hukukçuları daha önceden, Anglosakson hukuk sitemiyle ortaya çıkan, alternatif uzlaşma yöntemi olan arabuluculuğu; arabuluculuk ismiyle olmasa da sulh tahkim gibi kavramlar içerisinde değerlendirmişlerdir.

Arabuluculuk, tahkim, sulh ve muhâkemeden ayrı özellikleriyle yargıya yardımcı olan bir çözüm yöntemidir. Arabuluculukta nihai imzalanan bir akit olmaması yönüyle sulhtan, tarafların karar vermesiyle tahkimden, ispat vasitaları kullanılmamasıyla yargılama aşamasından ayrılmaktadır.

Profesyonel düzeyde arabuluculuk yöntemi, nihai aşama olan mahkeme kararına ulaşmadan, tarafların rızasına uygun olarak gerçekleşmesi durumunda kin, nefret, niza, sosyal kargaşa, haksızlık gibi toplumu sarsan etkileri sona erdirecek, toplumsal barışın kurulmasına yardımcı olacaktır.

Arabulucuda bulunması gereken tipik şartlar yanında, iletişimi sağlayan hukuk formasyonuna sahip kişi olması sürecin hızlı olmasında son derece önemi haizdir. Arabuluculuk, uyuşmazlıkları tahlil etme, tarafları aktif dinleme, ikna etme, soruna odaklaşma ve çözüm aşamalarından oluşur.

Osmanlı hukuk sisteminde önemli yeri olan ve Avrupa'da yaygınlaşan

138 Resmî arabulucuya başvurma tüzüğü md. 26, 29.

http://www.mevzuat.adalet.gov.tr/html/5133.html.

139 http://www.adalet.gov.tr/stratejikplan/AdaletBakanlı̆̆1StratejikPlanı 2010-2014.pdf (erişim tarihi: 30.09.2012); Daha geniş bilgi için bk. Arabuluculuk kanun tasarısı,

http://www.kgm.adalet.gov.tr/tbmmkom/arabuluculuk.pdf (erişim tarihi: 30.09.2012).

Hitit Üniversitesi İlahiyat Fakültesi Dergisi, 2012/2, c. 11, sayı: 22 
arabuluculuk müessesesi, Türkiye' de geleneksel boyutta olmakla birlikte yeni yeni kullanılmaya başlanmıştır. Toplumlarda uyuşmazlıklar ve hak ihlalleri bu yöntemin kullanılmamasından dolayı mahkemelere intikal etmiş ve davalar, altından kalkılamaz duruma gelmiştir.

İnsanlar arasında uyuşmazlıkları önlemek için İslâm'ın koymuş olduğu esaslar vardır. Bunlardan biri olarak değerlendirdiğimiz, temelde İslâm hukukunun kaynakları Kur'an ve Hadislerde teşvik edilen arabuluculuk, niza ve ihtilafları daha kolay bir şekilde sona erdirmekte ve mutlu bir toplum oluşturmaya katkı sağlamaktadır. İslâm, insanların birbirine güvendiği, aralarında kin ve hasedin, hak ihlallerinin olmadığı, zarûri maslahatların gerçekleştiği sağlıklı bir toplum hedeflemektedir. İslâm, bu hedefe ulaşabilmek için, insanları mahkemelerden kurtaracak ve değişen zamana göre mahkemelerin iş yükünü azaltacak olan arabuluculuğu ve bu çerçevede arabuluculuk müessesesinin çalışt1rılmasını teşvik etmiştir.

\section{Kaynakça}

Abacı, Z. Dörtop, “Bir Sorun Çözme Yöntemi Olarak Sulh:18. Yüzyıl Bursa Kadı Sicillerinden Örnekler ve Düşündürdükleri" Otam Dergisi, Ankara 2006, sayı: 20, ss.105-115.

Abdunnûr, Mahmûd Mahcûb, es-Sulh ve eseruh fî inhâi'l-husûme fi'l-fikhı'l-İslâmî, Beyrut 1987.

Abdülmelik b. Hişâm, Ebû Muhammed Abdülmelik b. Hişâm, es-Sîretü'n-nebeviyye, tahk.: Mustafa es-Sakka, Kahire 1955.

Acun, Necla, Kişiler Arası İlişkiler ve İletişimde Empati, Alim Kaya (edit.), Pegem Akademi, Ankara 2010.

Ahmed İbn Hanbel, Ahmed b. Muhammed (ö.241/855), el-Müsned, Çağrı Yay., İstanbul 1992.

Akgündüz, Ahmet, "Hakem" DİA, İstanbul 1997, c.15, s.172.

Atar, Fahrettin "Mahkeme", DİA, İstanbul 2003, c. 27, s. 338,340.

Atar, Fahrettin, "Sulh", DíA, İstanbul 2009, c. 37, s. 481.

Atar, Fahrettin, Fıkıh Usûlü, MÜİF. Yay., İstanbul 1992.

Atar, Fahrettin, İslâm Adliye Teşkilâtı, Diyanet İşleri Başkanlı̆̆ı Yay., Ankara 1991.

Ateş, Süleyman, Kur'an Ansiklopedisi, Kur'an Bilimleri Araştırma Vakfı, İstanbul ts.

Avdeh, Abdulkadir, et-Teşri'u'l-cinâi'l-İslâmî mukârenen bi'l-kânûni'l-vad'i, Dârü'l-Kütübi'l-Arabi, Beyrut ts.

Aydın, M. Akif, “Mahkeme”, DIA, İstanbul 2003, c. 27, ss. 342-344.

Aynî, Ebû Muhammed Mahmud b. Ahmed, el-Binâye fî şerhi'l-hidâye, Daru'1 Fikr, Beyrut 1990.

Bardakoğlu, Ali, "Hak", DİA, İstanbul 1997.

Bayındır, Abdülaziz, İslâm Muhâkeme Hukuku, İslâmî İlimler Araştırma Vakfı Yay., İstanbul 1986. Berki, Ali Himmet, Açıklamalı Mecelle, Hikmet Yay., İstanbul 1990.

Beyhakî, Ebû Bekr Ahmet b. el-Hüseyn b. Ali (ö.458/1066), es-Sünenü'l-Kübrâ, Matbaatü Meclisi Dâireti'l-Maarifi'l-Osmâniyye, Haydarabad 1354. 
Bilmen, Ömer Nasuhî, Hukukı İslâmîyye ve Istılahatı Fıkhıyye Kamusu, Bilmen Yay., İstanbul 1986. Buhâri, Ebu Abdillah Muhammed b. İsmail (ö.256/869), Sahîhu'l-buhârî, Çağrı Yay., İstanbul 1992. Cassâs, Ebû Bekr Ahmed b. Ali er-Râzî (ö.370/980), Ahkâmü'l-Kur'ân, tahk.: Abdüsselâm Muhammed Ali Şahin, Dâru'l-Kütübi'l-İlmiyye, Lübnan 2007.

Cihangir, Zeynep, Kişilerarası İlişkiler ve İletişimde Dinleme, Alim Kaya (edit.), Pegem Akademi, Ankara 2010, s. 109.

Çeker, Orhan, İslâm Hukukunda Akitler, İttifak Holding Yay., Konya 1999.

Çeliker, Hüseyin “İslâm Hukukunda Tahkim”, Diyanet İlmi Dergi, Ankara 2005, c. 41, sayı: 1, ss. 1746.

Dağcı, Şamil, İslâm Ceza Hukukunda Şahıslara Karşı Müessir Fiiller, Diyanet İşleri Başkanlığı Yay., Ankara 1996.

Dûrî, Kahtân Abdurrahman, Akdü't-tahkîm fi'l-fikhi'l-İslâmî ve'l-kânûni'l-vaz'î̀, Bağdat 1985.

Ebû Dâvûd, Süleyman b. Eş'as es-Sicistânî el-Ezdî (ö.275/889), es-Sünen, Çağrı Yay., İstanbul 1992.

Erdoğan, Mehmet, Fıkıh ve Hukuk Terimleri Sözlüğü, Ensar Neşriyat, İstanbul 2010.

Hâkim Nisâbûrî, Ebû Abdullah Muhammed b. Abdillah b. Muhammed (ö.405/1014), el-Müstedrek ale's-sahîhayn, Mektebü'l-Matbûati'l-İslâmiyye, Beyrut, ts.

Hamidullah, Muhâmmed, el-Vesâiku's-siyâsiyyetü li'l-ahdin-nebevîyyi ve'l-hilâfeti'r-râşide, Daru'nNefâis, Beyrut 1985.

Hamidullah, Muhâmmed, İslâm Peygamberi, çev.: Salih Tuğ, İrfan Yay., İstanbul 1991.

Hammad, Nezih, Akdü's-sulh fi'ş-şerîati'l-ìslâmiyye, Beyrut 1996.

Hasan, H.İbrahim, İslâm Tarihi, 2. Baskı, Kayıhan Yay. ,İstanbul 1987.

Heyet, el-Fetevayi hindiyye, Bulak 1310.

http://wiki.hukuki.net/Hukuk_sistemleri (erişim tarihi: 12.04.2012)

http://www.adalet.gov.tr/stratejikplan/AdaletBakanlığ1StratejikPlan2010-2014.pdf. (erişim tarihi: 04.08.2011)

http://www.kgm.adalet.gov.tr/tbmmkom/arabuluculuk.pdf.(erişim tarihi: 29.07.2011)

http://www.kgm.adalet.gov.tr/tbmmkom/arabuluculuk.pdf.(erişim tarihi: 29.07.2011)

http://www.mevzuat.adalet.gov.tr/html/5133.html.(erişim tarihi: 11.08.2011)

http://www.musiad.org.tr/img/yayinlarraporlar/cerceve_dergisi_48_20 (erişim tarihi: 11.8.2011).

İbn el-Kayyim el-Cevziyye, Şemsüddîn Ebî Abdillah Muhâmmed (ö.751/1350), I'lâmü'l-muvakkînn an rabbi'l-âlemîn, Dâru'l-cîl, Beyrut, ts.

İbn el-Kayyim el-Cevziyye, Şemsüddîn Ebî Abdillah Muhâmmed (ö.751/1350), et-Turuku'l-hukmiyye fis-siyâseti'ş-şeriyye, Mektebetü Dâri'l-Beyan, Beyrut 1989.

İbn Ferhun, Burhanuddin İbrahim b. Ali b. Ebi'l-Kasım b. Muhammed Ibn Ferhûn, Tabsiratü'lhukkâm fì usûli'l-akdiye ve menâhicu'l-ahkâm, Mısır 1301.

İbn Hazm, Ebû Muhâmmed Ali b. Ahmed(ö.456/1063), el-Muhalla, tahk.: Muhammed Münîr, İdaratü't-Tibâati'l-Münîriyye, Misır 1352.

İbn Kesîr, Ebu'l-Fidâ İsmail, Tefsiru'l-Kur'âni'l-azîm, Müessesetü Kurtuba, tahk.: Mustafa es-Seyyid Muhammed, yy, ts.

İbn Kudâme, Muvaffakuddîn, e'ş-Şerhu'l-kebîr (el-Muğnî ile birlikte), Beyrut 1972.

İbn Rüşd, Ebu'l-Velîd Muhammed b. Ahmed (ö 595/1199), Bidâyetü'l-müctehid ve nihâyetü'l-muktasıd, Dâru'l-marife, Beyrut 1997.

İbn Sa'd, Ebû Abdillah Muhammed, et-Tabakâtü'l-kübrâ, Beyrut 1985. 
İsfehâni, el-Hüseyin b. Muhâmmed er- Râgıp (ö.565/1169), el-Müfredât fi garibi'l-Kur'an, Kahraman Yay., İstanbul 1986.

Karafî, Şihâbuddîn Ahmed b. İdris, ez-Zehîra, tahk.: Muhammed Haciy, Daru'l-Garbi'1 İslâmî, Beyrut 1994.

Karaman, Hayreddin, Bă̆layıcılık Bakımından Resûlullah'ın Davranışları, (Hz peygamber ve Aile Hayatı içinde), İlmi Neşriyat, İstanbul 1989.

Karaman, Hayreddin, İslâmın Işı̆̆̆ında Günün Meseleleri, İstanbul 1992.

Kurtubî, Ebû Abdillah Muhâmmed b. Ahmed Ebû Bekir (ö.671/1273), el-Câmi' li ahkam'il Kur'an, tahk.: Abdullah b.Abdülmuhsin Müessesetür-Risale, Beyrut 2006.

Mâverdî, Ebû'l-Hasan Ali b. Muhammed b.Habîb (ö.450/1058), el-Ahkâmu's-sultâniyye ve'lvelâyâtu'd-dîniyye, Dâru'l-Kütübi'l-İlmiyye, Beyrut, ts.

Mâverdî, Ebû'l-Hasan Ali b.Muhammed b. Habîb (ö.450/1058), el-Hâvi'l-kebîr fî fikhi mezhebi'l-imam eş-şafî̀ ve hüve şerhu muhtasari'l-müzenî tahk.: Şeyh Ali Muhammed Muavvıd, Şehy Adil Ahmed Abdul Mevcut, Daru'1 Kütübi'l-ilmiyye, Beyrut 1994.

Mavsılî, Abdullah b. Mahmud b. Mevdud (ö.683/1284), Kitâbu'l-ihtiyar li ta'lîli'l-muhtar, Dâru'lMa'rife, Beyrut 2010.

McGillis Daniel, Community Mediation Programs; Development and Challenges Us Department of justice, Washington 1997.

Moore Christopher W., The Mediation Process: Practical Strategies for Resolving conflict, San Francisco: Jossey-Bass, 2003.

Müslim, Ebu'l-Huseyn Müslim b. el-Haccac el-Kuşeyri en-Nisabûrî (ö.261/874), el-Câmiu's-sahîh, Çağrı Yay., İstanbul 1992.

Necdî, Abdurrahman b. Muhammed, Hâşiyetü'r-ravzı'l-mürbi', Beyrut 1983.

Özbek, Abdullah, Bir Eğitimci Olarak Hz. Muhammed, Esra Yay., Konya 1991.

Özbek, Mustafa Serdar, "Alternatif Uyuşmazlık Çözüm Yollarına Genel Bir Bakış”, Galatasaray Üniversitesi Hukuk Fakültesi Dergisi, İstanbul 2004, say1: 1, ss. 261-292.

Sarah ve Bermen, Greg, Good Courts: The Case for Problem- Solving justice, New Press, Newyork 2005.

Serahsî, Muhâmmed b. Ahmed. Ebi Sehl Şemsuddin (ö.490/1097), el-Mebsût, Daru'1-Ma'rife, Beyrut 1989.

Serahsî, Muhâmmed b. Ahmed. Ebî Sehl Şemsuddin (ö.490/1097), Usûl, Dâru'l-Kütübi'l-İlmiyye, Beyrut 1993.

Şafak, Ali, Hukuk Terimleri Sözlüğ̈̈, Rehber Yay., Ankara 1992.

Şer'iye Sicilleri, Türk Dünyası Araştırma Vakfı Yay., İstanbul 1989.

Şeyzerî, Abdurrahman b. Nasr, İslâm Devletinde Hisbe Teşkilâtı, haz.: Abdullah Tunca, Ma'rifet Yay., İstanbul 1993.

Şîrâzi, Ebû İshak İbrahim b. Ali b.Yûsuf el-Fîrûzâbâdî, el-Mühezzeb fî fikhi mezhebi'l-imâm eş-şâfiî, tahk.: Adil Ahmed Mevcûd, Daru'l-Ma'rife, Beyrut 2003.

Taberî, Ebû Ca'fer Muhammed b. Cerîr, Câmiu'l-beyân an te'vîli ayi'l-Kur'an, Mektebetü İbn Teymiyye, Kahire 1968.

Tâhir b. Âşûr, Muhammed, İslâm Hukuk Felsefesi, çev.: Mehmet Erdoğan, Vecdi Akyüz, Rağbet Yay., İstanbul 2006.

Tanrıver, Süha, "Hukuk Uyuşmazlıkları Bağlamında Alternatif Uyuşmazlık Çözüm Yolları ve Özellikle Arabuluculuk", Türkiye Barolar Birliği Dergisi, Ankara 2006, say1: 64, ss. 165-166.

Tarablûsî, Alâuddîn Ebu'l-Hüseyn Ali b. Halil, Muînu'l-hükkâm fî mâ yeteraddedu beynel-hasmeyn 
mine'l-ahkâm, Misır 1973.

Tirmîzî, Ebû Îsâ Muhammed b. Îsâ b. Servet (ö.279/892), es-Sünen, Çağr1 Yay., İstanbul 1992.

Türk Hukuk Lügati, Maarif Matbaası, Ankara 1944.

Wensinck, el-Mu'cemül-müfehres li'l-elfâzı'l-hadîsi'n-nebeviyyi, Çağrı Yay., İstanbul 1988.

Yaman, Ahmet, “Sulh” DİA, İstanbul 2009, c. 37, ss. 485-489

Yaylalı, Davud, İslâm Hukukunda Sulh, Taştan Matbaacilık, İstanbul 1993.

Yazır, Muhammed Hamdi, Hak Dînî Kur'an Dili, Eser Neşriyat, İstanbul 1971.

Yıldırım, Mustafa, “Tahkim” DİA, İstanbul 2010, c. 39, ss. 411-413.

Yiğit, İsmail,"Siffîn Savaşı", DİA, İstanbul 2009,c. 37,s. 108.

Zeylâî, Fahruddîn Osman b. Ali (ö7431342),Tebyînu'l-hakâik şerhu kenzi'd-dakâik, Dâru'l-Kütübi'lilmiyye, Beyrut 2000.

Zerkâ, Mustafa Ahmed, el-Fıkhu'l-İslâmî fí sevbihi'l-cedîd, Dâru'l-Fikr, Dımeşk 1967.

Zeydân, Abdulkerim, el-Vecîz fì usûli'l-fikh, Dersaadet, İstanbul, ts. 